IZA DP No. 7644

Job Satisfaction and Self-Selection into the Public or Private Sector: Evidence from a Natural Experiment

Natalia Danzer

September 2013 


\title{
Job Satisfaction and Self-Selection into the Public or Private Sector: Evidence from a Natural Experiment
}

\author{
Natalia Danzer \\ Ifo Institute, University of Munich (LMU) \\ and IZA

\section{Discussion Paper No. 7644} \\ September 2013
}

\author{
IZA \\ P.O. Box 7240 \\ 53072 Bonn \\ Germany \\ Phone: +49-228-3894-0 \\ Fax: +49-228-3894-180 \\ E-mail: iza@iza.org
}

Any opinions expressed here are those of the author(s) and not those of IZA. Research published in this series may include views on policy, but the institute itself takes no institutional policy positions. The IZA research network is committed to the IZA Guiding Principles of Research Integrity.

The Institute for the Study of Labor (IZA) in Bonn is a local and virtual international research center and a place of communication between science, politics and business. IZA is an independent nonprofit organization supported by Deutsche Post Foundation. The center is associated with the University of Bonn and offers a stimulating research environment through its international network, workshops and conferences, data service, project support, research visits and doctoral program. IZA engages in (i) original and internationally competitive research in all fields of labor economics, (ii) development of policy concepts, and (iii) dissemination of research results and concepts to the interested public.

IZA Discussion Papers often represent preliminary work and are circulated to encourage discussion. Citation of such a paper should account for its provisional character. A revised version may be available directly from the author. 


\title{
ABSTRACT
}

\section{Job Satisfaction and Self-Selection into the Public or Private Sector: Evidence from a Natural Experiment}

\begin{abstract}
Are public sector jobs better than private sector jobs? To answer this question, this paper investigates observed differences in job satisfaction between public- and private-sector workers and disentangles the effect of worker sorting from the one caused by sector-specific job characteristics. A natural experiment - the massive privatization process in post-Soviet countries - allows correcting potential self-selection bias. Industry-specific privatization probabilities are assigned to workers based on unique individual-level survey information regarding pre-determined Soviet jobs during the 1980s. The results reveal a causal publicsector satisfaction premium and a negative selection of individuals into the public sector. Part of the public-private satisfaction gap can be explained by the different availability of fringe benefits in the two sectors.
\end{abstract}

JEL Classification: J28, J45, J31, J32

Keywords: public sector, job satisfaction, self-selection, quasi-experiment, privatization, fringe benefits

Corresponding author:

Natalia Danzer

ifo Institute

ifo Center for Labour Market Research and Family Economics

Poschingerstr. 5

81679 Munich

Germany

E-mail: danzer@ifo.de

\footnotetext{
* I am very grateful to Andrew Clark, Victor Lavy and Jonathan Wadsworth for valuable comments and discussions. I also benefited from inspiring feedback from J. David Brown, Alexander M. Danzer, Peter Dolton, Francesco Fasani, Colin Green, Helmut Rainer, Andrew Oswald, Chiara Rosazza-Bondibene, Analía Schlosser, Anna Vignoles, and participants at the Annual Conferences of the Scottish Economic Society and the Royal Economic Society as well as from seminar participants at the Royal Holloway College and Milan University. Sincere thanks to IZA, the ULMS consortium and the DIW Berlin for making the dataset available and to Natalia Kharchenko and Volodymyr Paniotto at KIIS for helpful information on the survey and the dataset. Thank you to Norberto Pignatti and Lena Ruckh for kindly sharing their retrospective ULMS data files with me and to Alexander Danzer for providing me with the relevant data extract from the UHBS needed for calculating the second instrument.
} 


\section{Introduction}

Do public sector worker receive rents? This paper revisits the research on publicprivate wage differentials from a subjective well-being perspective by analyzing differences in job satisfaction between state and private sector employees. While several recent studies found public-sector workers to be on average more satisfied with their jobs than private-sector workers this paper investigates the reason for this difference. ${ }^{1}$ In particular, it empirically investigates whether public-private satisfaction gaps represent rents - that is, genuine differences in objective job and workplace characteristics - or whether they are artificially created by non-random self-selection of workers based on unobservable personality traits.

Economists have long been interested in public-sector labor markets due to the public sector's sheer size and its distinct characteristics and objectives that guide decision making (e.g., collective wage setting, affirmative action) (Blank 1985; Ehrenberg and Schwarz 1987; Gregory and Borland 1999). In times of high budget deficits, it is also debated whether public-sector workers are over-compensated. This debate has not only fiscal implications (as public-sector wages must be borne by taxpayers), but affects also the private sector in terms of hiring and labor costs. The extensive theoretical literature - dating back to Adam Smithprovides several explanations for wage differentials between industries or sectors and why it might be optimal for certain firms to pay higher wages than others. One the one hand, wage differences could reflect compensating differentials (monetary compensation for unpleasant job aspects), implying market-clearing wages (Rosen 1987). On the other hand, these differences could represent "rents" which may be driven by efficiency wages, rent-sharing motives, union bargaining power, or political economy considerations (Katz and Autor 1999).

The classic empirical examination of sector wage differentials faces two major challenges which the present study meets in the following way: first, the concept and measurement of utility and disutility of labor. This would require a comprehensive measure for total compensation (including non-wage pecuniary components and fringe benefits) as well as a sound assessment of all job disamenities—both of which are extremely difficult to

\footnotetext{
${ }^{1}$ Economic studies with an explicit focus on public-private sector job satisfaction differentials are: Clark and Senik (2006) for France and the United Kingdom; Demoussis and Giannakopoulos (2007) for Greece; Ghinetti (2007) for Italy; Heywood, Siebert, and Wei (2002) for the United Kingdom; Luechinger, Meier, and Stutzer (2008) for 25 European and 17 Latin-American countries (analysis of life satisfaction); Luechinger, Stutzer, and Winkelmann (2006) for 20 European countries and (2010) for Germany.
} 
obtain. $^{2}$ In the following empirical analysis, this challenge is addressed by focusing on job satisfaction. The virtue of job satisfaction as a single measure is that it represents a comprehensive assessment of all relevant job aspects, both amenities and disamenities, and thus overcomes the problem of assessing pecuniary and non-pecuniary job aspects (Hamermesh 2001). Hence, to the extent that differences in job satisfaction reflect an unequal distribution of relative net advantages across sectors, the following analysis can detect sectorspecific rents and thus extend previous studies focusing on objective earnings measures.

The second challenge relates to unobserved heterogeneity among workers and the need to account for possible self-selection into sectors. If certain sectors attract workers with higher productivity or unobservable ability, simple least squares estimates of the wage premium in this sector will be upward biased (Gibbons and Katz 1992). Correcting the potential endogeneity of sector affiliation is crucial for identifying true sector differences and yet non-trivial. In an ideal experimental setting, the problem of self-selection could be ruled out by randomly assigning individuals to either the public or the private sector. Since such a randomized experiment is unfeasible, the identification strategy of this study uses a unique natural experiment that generated exogenous variation in the share of public-sector employment. The tremendous changes in enterprise ownership structure in Eastern Europe's transition countries - from a situation of exclusive state ownership of all firms to a mixture of privately and publicly owned firms - de facto randomly reallocated workers conditional on their observables from the public to the private sector. The data come from a unique and nationally representative survey of post-Soviet Ukraine (2003-2007) that contains almost complete retrospective individual work histories since Soviet times.

This paper makes four contributions to the literature. First, in contrast to earlier studies on public-private sector satisfaction differentials, this paper exploits a natural experiment to correct for worker self-selection. Identification of the pure sector satisfaction differential is based on exogenous variation in the ownership structure of firms stemming from the largescale privatization program accompanying the transition from a centrally planned to a market economy. Second, the paper adds to the empirical evidence on inter-sector wage differentials by providing indirect evidence of non-equalizing differences in total compensation as measured by significant public-private job satisfaction gaps. Third, detailed survey information on fringe benefits and payment schemes allows an assessment of whether the

\footnotetext{
${ }^{2}$ Hamermesh (1999) provides an early account of the role of non-pecuniary aspects in the development of overall earnings inequality in the United States. The most comprehensive attempt to measure total compensation in the public and private sectors is by Danzer and Dolton (2011), who combine various data sources to account for differences in, e.g., pension schemes, fringe benefits, and unemployment risks, in the United Kingdom.
} 
public-sector satisfaction premium is driven by additional benefits. This analysis contributes to the literature on the importance of job amenities and payment schemes for job and life satisfaction (e.g., Helliwell and Huang 2010). Fourth, the paper analyzes job satisfaction in a dynamically emerging economy based on a nationally representative dataset.

The results indicate that there indeed exists a causal positive and significant public sector satisfaction premium. This implies that Ukrainian workers enjoy rents by working for a public sector firm or organization. Part of these genuine differences between public and private sector jobs can be attributed to pecuniary and non-pecuniary fringe benefits which are more prevalent in the public than in the private sector. However, after correcting for selfselection and controlling for differences in various job (dis)amenities and fringe benefits, there remains a significant public-private job satisfaction gap.

The remainder of the paper is organized as follows. The next section discusses the empirical problem of estimating the public-private job satisfaction differential faced in the previous literature and describes the identification strategy of this paper as well as relevant institutional background. Section 3 contains provides information on the dataset and on the construction of the instrumental variables. The main regression results as well as several robustness checks are presented in Section 4. The role of sector differences in the provision of pecuniary and non-pecuniary benefits is assessed in Section 5. Section 6 concludes.

\section{Identification Strategy and Institutional Background}

In market-based economies, the observed allocation of workers in the labor market is the outcome of a selection and sorting process through which individuals (and firms) search and find their best matching jobs (and employees) according to their characteristics, preferences, and information sets. Several empirical studies show that employees report higher levels of job satisfaction the better the job matches their skills (Belfield and Harris 2002; Vieira 2005) implying utility gains from sorting in the labor market (Luechinger, Stutzer, and Winkelmann 2006). However, a priori, there are no reasons why this sorting process should lead to systematic higher job satisfaction levels in the state than in the private sector (in a well-functioning labor market). And yet, the majority of the empirical studies on the satisfaction differential between public- and private-sector workers find a public-sector satisfaction premium (e.g., in Germany, Greece, Italy, and the United Kingdom).

One potential explanation for the observed job satisfaction gap are comparatively good remuneration packages (including non-pecuniary job amenities) and working conditions in the 
public sector. Sector differences in job and income security may also play a role, especially during economic recessions (Luechinger, Meier, and Stutzer 2010). Public sector jobs could also act as partial insurance of households against income risks in developing countries (Rodrik 2000). ${ }^{3}$ Thus, if public-sector jobs were "truly better" and there were queues for them (Krueger 1988), then, on average, satisfaction levels should be lower among private-sector employees. In this case, the public-sector satisfaction premium would reflect "rents" (Clark and Senik 2006; Luechinger, Meier, and Stutzer 2008; Luechinger, Stutzer, and Winkelmann 2010). A random reallocation of workers would not erase the observed satisfaction gap (i.e., the positive public-private satisfaction gap would remain after correcting for self-selection).

An alternative explanation posits that worker characteristics that drive the sorting process are correlated with unobserved intrinsic levels of happiness. Even if both sectors were similarly attractive, the sorting would imply a nonrandom allocation of workers in terms of their inherent satisfaction levels. In this scenario, the positive public-private satisfaction gap would only be spuriously caused by the fact that individuals from the upper part of an underlying satisfaction distribution sort into the public sector (Heywood, Siebert, and Wei 2002). Ignoring such a self-selection of workers in the empirical estimation would yield biased estimates of the true public satisfaction premium, while correcting for this type of selection should eliminate the spurious satisfaction premium.

To date, empirical attempts to account for the problem of self-selection rely either on panel methods (controlling for individual fixed effects: Clark and Senik 2006; Heywood, Siebert, and Wei 2002), or on estimating endogenous switching regression models (Luechinger, Stutzer, and Winkelmann 2006, 2010). Nevertheless, panel estimates could still be biased since sector switching decisions are endogenously determined. ${ }^{4}$ Furthermore, particularly low levels of job satisfaction prior to a voluntary leave (Boswell, Boudreau, and Tichy, 2005) lead to overstating the true gain in satisfaction (similar to the Ashenfelter dip; Ashenfelter (1978))..$^{5}$ Consequently, standard panel data techniques are limited in their ability to evaluate causal effects in the presence of self-selection. As regards switching regression models, their identification rests on particular - and partly very restrictive-functional form assumptions and ultimately requires valid instruments to act as exclusion restrictions in the

\footnotetext{
${ }^{3}$ Another — unwanted and unintended — reason might be bribes (Luechinger, Meier, and Stutzer 2008).

${ }^{4}$ Luechinger, Stutzer, and Winkelmann (2006) stress this point. This problem of fixed effects panel estimations is also addressed in the literature on wage differentials (e.g., Gibbons and Katz 1992).

${ }^{5}$ However, Clark, Diener, Georgellis, and Lucas (2008) show substantial anticipatory and adaptation effects of life events on life satisfaction (e.g., unemployment). If the same was true for job satisfaction and voluntary job changes, fixed effects models focusing on job switchers would underestimate the true satisfaction differential.
} 
selection equation. Luechinger, Stutzer, and Winkelmann $(2006,2010)$ employ as instruments the citizen status and parental occupation during childhood, respectively (in particular, whether the father was a civil servant, whether he was a white collar worker and whether the mother was working). However, as one cannot rule out that these instruments have a direct effect on job satisfaction (beyond affecting sector choice) their validity might be jeopardized. ${ }^{6}$

\subsection{Identification Strategy and Identifying Assumptions}

In contrast to previous work, the identification strategy in this paper takes advantage of a quasi-experiment created by the dramatic changes in the ownership structure of firms in Ukraine that occurred after the collapse of the Soviet Union. ${ }^{7}$ Within about 10 years, the share of private sector jobs in Ukraine grew from virtually zero to over 50 percent - due to largescale privatization of Soviet firms as well as the creation of new private firms (Figure 1). As a result, part of the exclusively state-sector Soviet work force was de-facto exogenously "reassigned" from the state to the private sector. However, even after the massive privatization and restructuring processes of the 1990s state-sector ownership in 2003 was still much more common in many industries than in advanced market economies. Owing to the availability in the data of Soviet era information on the allocation of workers into what would become state- or private-sector jobs in the data, the labor market sorting that took place after the collapse of the Soviet Union can be measured and corrected for.

\section{$<$ FIGURE $1>>$}

The empirical analysis thus can answer the question: "Do public sector worker receive rents or is the public job satisfaction premium simply driven by self-selection of workers?" The methodology relies on instrumental variable techniques to identify the causal effect of potential differences in workplace characteristics on job satisfaction. The constructed instrumental variable comprises an exogenous probability of working in the private sector in post-Soviet Ukraine based on pre-transition job characteristics (industry sector and geographical location). The instrumental variable represents an intention to treat (in the first stage), since not all individuals who were assigned to the treatment were actually treated. Some individuals in the treatment group might have forgone "treatment" because their firm

\footnotetext{
${ }^{6}$ Citizen status is strongly correlated with cultural background which in turn might affect job satisfaction. Father's occupational choice might be determined by unobserved characteristics which are intergenerationally transmitted and thus also simultaneously affect their offspring's sector choice and satisfaction levels.

${ }^{7}$ Focusing on another research question, Fuchs-Schündeln and Schündeln (2005) use a similar identifying assumption to exploit the German reunification "experiment" to purge the estimation of precautionary savings from possible self-selection bias into low-risk occupations. In their setup, reunification is interpreted as a "reassignment" of income risks for certain occupational groups.
} 
was never privatized or because they switched industries during the $1990 \mathrm{~s}^{8}$ The estimated effect must be interpreted as local average treatment effect (LATE) since identification stems from individuals who comply with their assigned treatment and switch sectors accordingly (Imbens and Angrist 1994).

For the identification strategy to be valid, the instrumental variables need to satisfy the exclusion restriction. Since the treatment variable is assigned according to Soviet industry (and region) affiliation, the exclusion requires that during Soviet times workers were randomly allocated across "would-be private" and "would-be public" industries (and regions) with respect to their intrinsic satisfaction levels. There are several reasons and particular features of the Soviet labor market why this identifying assumption is likely to hold (even more so when one considers a random allocation conditional on predetermined observable personal characteristics). First, from the perspective of a Soviet employee in the 1980s, the collapse of the Soviet Union with its economic and political implications was unexpected and unforeseeable. ${ }^{9}$ Hence, one can rule out anticipatory sorting behavior. Second, in the Soviet Union there was no private sector or any sector with features similar to those of the private sector of advanced market economies (e.g., profit-maximizing firms, competition, hard budget constraints, job uncertainty) and, hence, workers could not self-select themselves into firms or industry because of them being privately or publicly owned or showing features of typical "Western" private or public firms. Third, job security as well as the provision of fringe benefits did not differ across industries. Full employment was guaranteed by the constitution and implemented by the state. Wages, working hours, and working conditions were set centrally by the government, and the wage distribution was relatively compressed (see Brown 1973; Gregory and Collier 1988). Furthermore, social security, free medical services, social benefits, and fringe benefits were provided irrespective of economic or industrial sector (Flemming and Micklewright 2000; Friebel and Guriev 2005). Fourth, individual freedom to choose the field of study, one's employer or even one's region of living was extremely limited or not existent. Since the Soviet Union was run and organized along political motives and principles, individual educational paths and fields of specialization, as well as professional advancement, were more closely connected to political loyalty and political decisions rather than to individual ability or preferences (Titma and Roots 2006). According to estimates, about 60 to 70 percent of graduates were allocated to their first job by the government to meet labor requirements in certain industries and regions (Haddad 1972). In addition, individuals'

\footnotetext{
${ }^{8}$ In the sample, 55 percent of the workers work in the same industry they used to work in during Soviet times.

${ }^{9}$ Estrin, Hanousek, Kocenda, and Svejnar (2009) provide a recent review on the effects of privatization.
} 
labor market choices and mobility were limited due to the internal passport system as well as the administrative allocation of housing in the Soviet Union (Gregory and Kohlhase 1988). The spatial segregation of planned production limited the diversity of industries within certain regions (Friebel and Guriev 2005). In extreme cases, the entire population of an area was working in a single large state-owned enterprise (one-company towns). Against this background and given the particular features of the Soviet labor market, it seems plausible that the ex-ante privatization probability is unrelated to the intrinsic satisfaction levels of workers. Hence, the distribution of workers across different industries (within geographical regions) during the Soviet Union can be seen as a valid counterfactual against which the postSoviet allocation of workers across publicly and privately owned firms can be assessed.

Another important identifying assumption is that the instrument (the ex-ante privatization probability) has no direct effect itself on today's job satisfaction. This aspect is critically discussed below in the section on robustness tests, which also contains a sensitivity test with respect to those individuals who have personally experienced privatization in recent years and should be thus supposedly more strongly negatively affected (Section 4.3). However, when dropping these critical observations the results become even stronger. Finally, the instruments need to satisfy the monotonicity assumption as it likely does, because it is implausible that persons generally preferring to work in the private sector reverse their preferred choice due to being assigned to the private sector by the instrument.

\subsection{Evolution of the Private Sector in Post-Soviet Ukraine}

During the transition from a planned to a market economy a private sector evolved as the consequence of the privatization process, through which formerly state-owned entities were transferred to private ownership, and the creation of completely new firms (de novo firms), which had never been owned by the state. The privatization process in Ukraine started in 1992 and progressed more slowly than in most other Central and Eastern European countries (Brown, Earle, and Telegdy 2006). Between 1992 and 2004, more than 96,549 formerly state-owned entities were transferred to private ownership by means of privatization (State Statistics Committee of Ukraine 2005). Privatization took place in all industrial sectors, but the extent of privatization varied substantially across industries (see Section 3.2). The political goal to privatize quickly and socially acceptable, led to large-scale mass privatizations as predominant method (involving the distribution of free privatization certificates to citizens or share transfers to employees), especially in the early 1990s 
(Pivovarsky 2001). As Brown, Earle, and Telegdy (2006) point out, the privatization process was universal, implying that firms were less selectively and carefully chosen than typically done in Western countries. This fact further strengthens the validity of the identification strategy. Another important aspect is that there were only very few jobs that were ended mainly because of privatization and this is true for all industries (less than one percent). Figure 2 provides an overview of the reasons why jobs that started during the Soviet period were terminated during the transition process. The figure contains only answers related to the restructuring process. In the late 1990s and early 2000s the majority of jobs ended due to "personnel reductions," "closing down of enterprise," and "reorganization of enterprise".

\section{$<$ FIGURE $2>>$}

After its official start in 1992, the privatization process only gained momentum after the Ukrainian government launched a revised mass privatization program at the end of 1994, which had been prepared with the support of Western donors and advisors (USAID, World Bank, EU, and EBRD) (USAID 1999). ${ }^{10}$ The program's goal was to privatize the universe of Ukraine's approximately 10,000 medium and large industrial enterprises by 1998 based on the following objectives: (i) rapid and equitable distribution of shares to Ukrainian citizens, (ii) development of capital markets and the respective infrastructure, and (iii) quick creation of a critical mass of privately owned enterprises that would trigger relevant modernization processes in the economy (USAID 1999). ${ }^{11}$ Generation of state revenues was not a primary aim of the mass privatization program (Grygorenko and Lutz 2007). In addition to the mass privatization of medium- and large-scale enterprises, about 40,000 shops and retail establishments were privatized by means of employee buyouts or cash auctions. Owing to the design of the mass privatization program the resulting ownership became widely dispersed and dominated by insiders (managers and workers) (Grygorenko and Lutz 2007).

Apart from privatization, the destruction and creation of firms affected the share of private employment across industry sectors and also caused a shrinking of some industries (manufacturing) and growth of others (services). Some individuals may have been forced to

\footnotetext{
${ }^{10}$ The Ukrainian Parliament approved the law on the First Privatization Program in July 1992 (Verkhovna Rada: The State Privatization Program for 1992; see Grygorenko and Lutz 2007).

${ }^{11}$ Mass privatization in Ukraine was carried out by distributing privatization certificates or vouchers to all citizens. These vouchers could be used to purchase shares of enterprises. Preferential purchase rights were given to employees and managers and remaining shares were sold to other persons holding privatization certificates (USAID 1999). In the largest enterprises, about 25 percent of shares were sold to employees and the public, the state initially kept between 25 to 51 percent of shares (especially in so-called strategic enterprises), and the remaining shares were sold via cash and/or investment tenders or local stock exchange sales (USAID 1999). In 1995, the Ukrainian Parliament issued a list of 5,200 "enterprises banned from privatization in view of their importance for the national economy." These were mainly enterprises in the energy sector (power networks and energy systems, hydro and nuclear power stations, combined heat and power stations) (USAID 2000).
} 
leave their state-sector employment due to plant closure and seek new job opportunities elsewhere. Since the creation of new firms and jobs almost exclusively occurred in the private sector, these structural changes de facto also reallocated individuals into the private-sector.

\section{Dataset, Variables, and Sample Description}

The analysis is based on the Ukrainian Longitudinal Monitoring Survey (ULMS), a nationally representative panel dataset of individuals aged 15 to 72 who were interviewed in three waves in the years 2003, 2004, and 2007. ${ }^{12}$ The survey provides detailed information on individual labor market activity, workplace and job characteristics, plus all relevant individual and household socio-demographic characteristics.

Two special features make this dataset unique and especially suitable for addressing the research question. First, the data provide detailed retrospective information about the individuals' labor market activities and job characteristics during the time of the Soviet Union as well as individual labor market histories during the transition process, including information on whether and, if so, when their workplaces were privatized. ${ }^{13}$ Specifically, respondents were asked to provide labor market information for December 1986 and December 1991, as well as a complete job history spanning the years 1997-2007. The years 1986 and 1991 were chosen because they are important years in Ukrainian history (Chernobyl catastrophe in 1986; 1991 as the year before independence) and so serve as memory anchors to reduce recall error (Ganguli and Terrell 2006). ${ }^{14}$ Altogether, there are 5,786 individuals in the cross-section 2003 for whom this Soviet labor market information is available, meaning that complete labor market information exists for almost all sampled individuals who were of working age when the Soviet Union collapsed (official unemployment was absent in the Soviet Union). The Soviet labor market information along with the privatization information is used to construct one of the instrumental variables. Second, the survey collects detailed ownership information about the respondents' current workplaces (13 different categories) and thus allows an exact classification of respondents into public or private employment. ${ }^{15}$

\footnotetext{
${ }^{12}$ The survey was conducted by the Kiev Institute for Sociology (KIIS) following a multistage sampling procedure. Details on the sampling procedure can be found in the technical reports provided by KIIS.

${ }^{13}$ The reliability of self-reported ownership status in the ULMS is discussed by Brown, Earle, and Vakhitov (2006), who use the ULMS to analyze wage and employment effects of privatization. They emphasize the careful wording and the fact that workers were directly involved in any privatization process, which likely increases the accuracy of the answers. However, a measurement error in this variable (state-sector employment) should lead to a downward bias in the estimated coefficients.

${ }^{14}$ Furthermore, as wages were highly regulated and determined by a centralized wage grid during Soviet times the likelihood for correct recalls of Soviet wages should be high (Ganguli and Terrell 2006).

${ }^{15}$ This is an advantage compared to some datasets used in the previous literature that lack direct information on firm ownership (e.g., the European Social Survey used amongst other data sources in Luechinger et al. 2008).
} 
Regarding the sample for the job satisfaction analysis, there are 3,583 individuals in paid employment at the time of the interview in 2003 (see Table A 1 in the Online Appendix). Out of these, 2,556 held a job during Soviet times. Missing values in several variables reduce the number of observations to 1,491. The main estimation sample is based on observations from all three survey waves and includes all individuals who have a paid job at the time of the interview, yielding a pooled sample of 4,191 observations (unbalanced panel). ${ }^{16}$

The second, alternative instrumental variable is creating using the Ukrainian Household Budget Survey (UHBS). The UHBS is an annual cross-section of around 9,000 households and about 25,000 individuals and is conducted by the State Statistics Committee of Ukraine (UkrStat). Calculations of the instrumental variable are based on four survey years (2003-2006) and make use of the individual level labor market information on industrial sector, enterprise ownership, and place of residence.

\subsection{Dependent and Explanatory Variables}

The dependent variable, job satisfaction, is measured by the question "Tell me, please, how satisfied are you with your current job?" to which respondents can answer on a fivepoint Likert scale ranging from 1 (fully dissatisfied) to 5 (fully satisfied). This question can be interpreted as a comprehensive judgment of all relevant job aspects. The main analysis will employ this categorical dependent variable. ${ }^{17}$

\section{$<$ FIGURE $3>>$}

How satisfied are workers in the private and state sectors in post-Soviet Ukraine? Figure 3 presents the raw unconditional job satisfaction levels in both sectors for the pooled sample of workers. ${ }^{18}$ Almost twice as many workers in the private sector are entirely dissatisfied with their job (12.3 vs. 6.5 percent, respectively). Focusing on the other end of the spectrum, the share of fully satisfied workers in the public sector surpasses the one in the private sector by 5 percentage points. These distributions imply that state-sector workers are generally more satisfied with their jobs than are their private-sector counterparts. A similar

\footnotetext{
${ }^{16}$ As a sensitivity check, the main regressions are re-estimated based on a larger sample by dropping the variable measuring risk aversion, which was collected in 2007 only (this increases the pooled sample size to 5,142 observations; the 2003 sample increases from 1,491 to 2,059; see Table A 1, Online Appendix).

${ }^{17}$ Two surveys asked about job satisfaction during Soviet times: the World Values Survey 1981 (conducted in the Soviet region Tambov) and the Consolidation of Democracy in Central and Eastern Europe Survey of January 1991 (Ukrainian Soviet Socialist Republic). As both lack relevant variables they cannot be used to analyze the relationship between job characteristics and job satisfaction before the start of the transition process. ${ }^{18}$ Figure 3 is based on the sample used in the regressions. The picture remains almost the same when using the complete ULMS sample including young individuals (graph not shown, but available from author upon request).
} 
pattern in raw differences between public- and private-sector employees is found for other countries, such as Germany and the United Kingdom (Luechinger, Meier, and Stutzer 2008).

The main explanatory variable is the binary state sector indicator, identifying individuals working in state-owned as opposed to privately owned enterprises and organizations. The survey differentiates between 13 different types of ownership, out of which three can be unambiguously classified as state-owned enterprises and organizations (i.e., budgetary organizations, state enterprises, and local municipal enterprises). The remaining categories are classified as private ownership (newly established private enterprises, new private agricultural firms/farms, privatized enterprises, freelance work/selfemployment, international organizations, public/religious/self-financing organizations, collective or state farms, collective enterprises, cooperatives, other). ${ }^{19}$ Other control variables, which are successively added to the regressions, are (a) standard socio-demographic individual characteristics (including job-related pre-transition background information), (b) job characteristics, and (c) workplace characteristics. Two additional sets of variables will be included to investigate whether sector job satisfaction differences are driven by (d) personality traits or (e) differences in wages and pecuniary and non-pecuniary fringe benefits. A detailed description of all variables and the corresponding sector-specific summary statistics are provided in Table A 2 and Table A 3 in the Online Appendix.

The descriptive statistics of the two sectors reveal differences in workplace characteristics as well as in the composition of the workforce that are much in line with the typical findings for Western economies (see Gregory and Borland 1999): the share of women (men) is higher (lower) in the state sector. State-sector workers are on average more educated, slightly older, work fewer hours per week, and are more concentrated in high-skilled (professional and technical) occupations as well as in larger establishments than their colleagues in the private sector. Interestingly, the two wage measures indicate that earnings are on average lower in the state than in the private sector. Furthermore, state-sector workers seem to be more open (extrovert) on average, but at the same time less risk loving. Finally, the mean comparisons show that workers also differ with respect to their Soviet characteristics, reflecting simple age and gender composition effects as well as Soviet geographical and occupational (gender) segregation.

\footnotetext{
${ }^{19}$ The categories collective enterprise, new private agricultural firm/farm, and public/religious/self-financing organization were added to the survey in 2004.
} 


\subsection{Instrumental Variables}

Two instrumental variables were constructed to overcome the potential endogeneity of the state sector variable and to capture the two processes underlying the growing share of private-sector employment: one is based on the privatization process only; the other covers both the extent of privatization and the creation of new firms across industries. The instruments are constructed to reflect an ex-ante, exogenous probability of whether the enterprise where a worker used to work during Soviet times would eventually be privatized and become a private-sector workplace. This probability is assigned to each individual based on her Soviet job characteristics in December 1986 (two-digit industry sector and region). ${ }^{20}$

The first instrument (IV 1) was constructed using the detailed retrospective labor market information on individual privatization experience from the ULMS. In the first step a dummy variable was created identifying all jobs that started in the Soviet era, that is, up to December 1991, and that were privatized later on. Reported episodes of privatization were counted as privatized only if the majority of shares of the enterprise/organization were transferred to private ownership. ${ }^{21}$ In a second step, the share of these privatizations within each of 27 industry cells was computed (see Online Appendix B). ${ }^{22}$ These industry specific privatization probabilities were then assigned to individuals according to the industrial sector of their 1986 Soviet job. For instance, a construction worker in 1986 faced an exogenous privatization probability of about 13 percent, while the risk was about 35 percent for those in manufacturing of textiles and leather products. The advantage of using these cell probabilities instead of individual actual privatization episodes is that the latter might be plagued by selection bias (e.g., if certain types of workers leave their employer before privatization).

In contrast, the second instrument (IV 2) reflects the contemporary, post-Soviet share of all private sector jobs within 16 industries and five macro regions of Ukraine in the years 2003 to 2006 (i.e., all jobs other than those for the national/local government or state-owned enterprises). 23 In addition to private sector jobs in privatized enterprises this measure also counts jobs in newly established private companies. It thus captures the transition of the Ukrainian labor market more broadly. The calculation is based on pooled data from an alternative data source, the UHBS, creating 16 (industry) $\times 5$ (region) cell probabilities. This

\footnotetext{
${ }^{20}$ If respondents did not have a job in December 1986 (i.e. younger cohorts), the instrumental variable was assigned according to the industry affiliation of their December 1991 job.

${ }^{21}$ This information is provided by the survey respondents.

${ }^{22}$ Using this refined industry categorization with 27 economic sectors makes it impossible to take regional variation into account since cell sizes would become too small.

${ }^{23}$ The UHBS does not contain more disaggregated information on industrial sectors.
} 
instrumental variable was merged with the individual level ULMS data according to the industrial sector and the location of the workplace in December 1986.24 The correlation between the two instrumental variables is 0.75 . Figure 4 shows the calculated cell probabilities for both instruments (see Online Appendix B for more details).

\section{$<$ FIGURE $4>>$}

\section{Empirical Results: Public-sector Satisfaction Premium and Self- Selection of Workers}

The core of the empirical analysis estimates the following job satisfaction function:

$$
J S_{i}=\beta_{0}+\beta_{1} \text { state }+\mathrm{X}_{i}{ }^{\prime} \gamma+J_{i}^{\prime} \theta+P l_{i}{ }^{\prime} \delta+\varepsilon_{i}
$$

The outcome, job satisfaction, is explained by a binary variable indicating employment in the state sector, a set of individual present-day and Soviet time sociodemographic characteristics $\left(\mathrm{X}_{\mathrm{i}}\right)$, job and workplace characteristics $\left(\mathrm{J}_{\mathrm{i}}\right.$ and $\left.\mathrm{Pl}_{\mathrm{i}}\right)$, and a normally distributed error term. ${ }^{25}$ Although the dependent variable is categorical, standard linear estimation techniques - assuming cardinality_-will be applied and reported to simplify interpretation of the coefficients (specifically, random effects generalized least squares (GLS) and generalized two-stage least squares (G2SLS) for the pooled panel data sample; OLS and 2SLS for the sensitivity checks using the cross-section 2003 only). ${ }^{26}$ Even if these estimates are less efficient than models taking into account the ordinal nature of the dependent variable, the GLS estimates are consistent (under classical assumptions). ${ }^{27}$ Furthermore, whether one estimates cardinal (e.g., OLS, GLS) or ordinal (e.g., ordered probit or logit) models generally does not affect the results substantially (Ferrer-i-Carbonell and Frijters 2004).

The empirical analysis proceeds in the following steps. First, the sector affiliation of a worker will be taken as exogenously determined. To correct any bias stemming from composition effects, individual, predetermined control variables will be successively added to the regression equation. Since the private and public sectors might also differ in their

\footnotetext{
${ }^{24}$ A few respondents were not living or working in Ukrainian territory in December 1986 or 1991 . These persons were assigned to "private-sector shares" calculated from the UHBS based on industry affiliation only.

${ }^{25}$ In the panel data model, the error term comprises a time-invariant and a time-varying component. In this case, the instrument has to be uncorrelated with this composite error term in order for the instrumental variable random effects model to generate consistent estimates of the regression parameters.

${ }^{26}$ The GLS estimation accounts for the fact that the panel data have repeated observations for each individual and, hence, standard errors are likely to be correlated within units of observation (applying ordinary least squares might be inefficient). Fixed effect models cannot be applied since the instrumental variables are time invariant.

${ }^{27}$ The results hold when the equation is estimated by a more efficient random effect ordered probit model.
} 
distributions of job and workplace characteristics that may be correlated with job satisfaction, further controls for occupation, working hours and firm size will be added. However, these variables may already be capturing "rents" (e.g., when a particular number of working hours is seen as a job amenity) and could be endogenous if workers self-selected into specific occupations or firms. In a next step, average industry wages (official average wages at the one-digit industry classification level) as well as individual earnings will be added to the regression. Again, differential wage levels might be part of the "satisfaction premium" and hence any change in the state sector coefficient following the inclusion of wage information can be interpreted accordingly. However, individual income itself might also be endogenously determined (e.g., depending on positive or happy personality traits). Finally, further controls for potential job disamenities (shift work and weekend work) as well as several proxies aimed at capturing personality traits and risk aversion are added to the regression. However, all specifications including these possibly endogenous variables should be interpreted cautiously.

In the second part of the analysis, the state sector variable is no longer assumed to be exogenously determined. The existence of a binary endogenous regressor in addition to a limited dependent variable theoretically complicates the econometric approach (due to nonlinearities). However, following Angrist (2001), the estimation will rely on simple twostage least squares techniques for panel data models using the constructed instruments, since the main aim is estimation of the causal treatment effect. Furthermore, although the estimation of linear probability models (instead of probit models) in the first stage is less efficient, the estimated coefficients are consistent (Angrist 2001).

\subsection{Basic GLS Results}

Table 1 reports the GLS-RE estimates of job satisfaction in Ukraine based on the pooled sample (2003-2007) for different specifications (the complete set of estimated coefficients is provided in Error! Reference source not found. in the Appendix). ${ }^{28}$ The estimated coefficients of the state sector dummy variable are reported in the first row. The first column reveals a highly significant raw difference between satisfaction levels in both sectors of 0.34 , indicating that public-sector employees are significantly more satisfied with their jobs than are their private-sector counterparts. As expected, the inclusion of covariates to control for composition effects gradually reduces the size of the coefficient and leads to an

\footnotetext{
${ }^{28}$ Table A 4 in the Online Appendix also provides estimation results for further regression specifications. 
improvement in the overall model fit. Inclusion of general socio-demographic background characteristics and predetermined Soviet period variables reduces the coefficient to 0.266 (Column 3). Even in the specification with the most extensive set of control variables there remains a positive and statistically highly significant public-sector satisfaction premium of 0.212 (Column 4). The standard errors remain essentially constant across specifications.

\section{$<$ TABLE $1>>$}

Beyond the sector affiliation several interesting findings emerge. First, job satisfaction increases with educational attainment. However, these significantly positive effects of more education vanish as soon as occupational information is added to the regression. This indicates that occupations are quite segregated in terms of educational achievement. Throughout all specifications, the occupational dummy variables are highly significant. The higher the skill level of the occupation the higher the return in terms of job satisfaction. Joband workplace-specific variables are also related to satisfaction levels: average job satisfaction is significantly lower among employees working less than 30 hours a week.

The inclusion of individual earnings and average industry wages — both of which are positively associated with job satisfaction and statistically highly significant-generates two surprising effects. First, the coefficient of the state sector dummy increases slightly. If sector satisfaction differentials simply reflected wage differentials, one would expect the opposite effect. This implies also that public-private wage differences are not driving the observed public-sector job satisfaction premium. Second, gender differences become larger and significant only now, implying that the structurally higher wages for men hid a substantial gender gap in job satisfaction. Thus, once differences in earnings are controlled for the Ukrainian data reveal a satisfaction gender gap in line with the "contented female worker" phenomenon found in several Western countries (e.g., Clark 1997).

The average industry wage variable can also be interpreted as a crude measure for reference group income, which is often found to be negatively correlated with job satisfaction in Western market economies (i.e., job satisfaction decreases with increasing income of one's peers) (Clark and Oswald 1996; Clark, Frijters, and Shields 2008). However, Table 1 shows a positive coefficient which is in line with evidence of a positive effect of comparison income on life satisfaction in Russia, which Senik (2004) interprets as a "tunnel effect": in economically difficult and uncertain times, people interpret the wage levels of others as signals of their own future. Among the two measures of job disamenities, only weekend work 
is significantly negatively related to job satisfaction. Regarding the proxies for personality traits and risk aversion, only the coefficient for extroverted types is significantly positive.

\subsection{Results from the IV Regressions}

The results from the instrumental variable regressions in Table 2 aid in understanding the extent to which the previous findings are driven by a nonrandom self-selection of workers into particular sectors. For ease of comparison, Panel A of the table restates the GLS-RE results from the previous section. Panel B shows generalized two-stage least squares random effects (G2SLS-RE) panel estimates and the lower panels report the reduced form and firststage regression results. Three specifications were estimated using each instrumental variable separately: the simple raw mean comparison without any controls, the specification controlling for all predetermined and exogenous individual characteristics, and the specification controlling for the full set of variables, including wages and job- and firmspecific variables (corresponding to Columns 1, 3, and 4 of Table 1, respectively). In all regressions, standard errors are clustered on the individual level.

\section{$<$ TABLE $2>>$}

For both instruments, the first-stage results at the bottom of Table 2 point to a strong association between the instrumental variables and the endogenous binary state sector variable. The $\mathrm{z}$ and the chi-squared statistics (corresponding to $\mathrm{t}$ and $\mathrm{F}$ statistics in simple 2SLS estimations) have high values, indicating that the instrument has substantial predictive power. ${ }^{29}$ The significantly negative effects confirm that a higher probability of experiencing privatization or having been employed in a Soviet industry that was less likely to remain state owned reduces the likelihood of working in the state sector in post-Soviet Ukraine. The estimated first-stage coefficients (and the standard errors) using the first instrument (privatization) are almost twice as large as the estimates based on the second instrument (private-sector share). This can be explained by the fact that the second instrument has a much larger variation: its values range from about 0.0 to 0.48 , whereas the values of the second instrument (private-sector share) range from about 0.0 to 0.96 .

The estimates of the reduced-form regressions of job satisfaction on the instrumental variables are also highly significant across all specifications and show the expected sign. Conditional on individual predetermined characteristics, as well as on job and workplace characteristics, workers who used to work in Soviet industries (industries and regions) with

\footnotetext{
${ }^{29}$ Stock, Wright, and Yogo (2002) suggest a minimum critical F value of 10 for the instrument in the first stage.
} 
more privatizations (instrument 1) or general restructuring (instrument 2) report lower levels of job satisfaction. Turning to the upper part of Table 2, the results of the G2SLS-RE estimations confirm that the public-sector satisfaction premium found in the simple GLS-RE regressions persists even after correcting for self-selection into sectors. ${ }^{30}$ More precisely, the estimated 2SLS coefficients of the state sector dummy variable more than double compared to the GLS-RE estimates and remain highly significantly positive at the 1 percent significance level in almost all three specifications. Given the comparatively large G2SLS-RE standard errors, the estimates do not significantly differ from the GLS-RE estimates once controlling for demographic characteristics. In the specifications that do not control for earnings or industry wages (Columns 2 and 4), the estimated public-private satisfaction gap is about 0.39 (instrument 1) and 0.55 (instrument 2), which corresponds to roughly one-third and one-half of a standard deviation of job satisfaction, respectively (standard deviation 1.18). Using the coefficients based on the full set of covariates (Columns 3 and 6), the estimated public-sector satisfaction premium corresponds to about 42-44 percent of a standard deviation.

What can be inferred from these results about the process of self-selection? First, since the estimates increase after correcting for self-selection, the GLS-RE estimates seem to be downward biased and underestimating the true public-sector differential. One can safely conclude that the positive satisfaction gap is not caused by a spurious correlation between state-sector affiliation and individuals with inherently higher satisfaction levels. Second, the sorting and matching of workers across sectors led to a reduction in the satisfaction gap, since the observed gap in job satisfaction between private and state workers (GLS-RE) becomes larger under random assignment (G2SLS-RE). This sorting process channeled workers with low intrinsic job satisfaction into the public sector and workers with higher intrinsic job satisfaction into the private sector (negative selection into the public sector). These results of a negative selection into the public sector are in line with evidence for Germany (Luechinger, Stutzer, and Winkelmann 2010). It seems that in an emerging economy like Ukraine, more extroverted and optimistic individuals discover their entrepreneurial talents and sort into the private sector. This explanation fits well with the fact that productive high ability workers exit the public sector which is characterized by a relatively compressed wage distribution (Gregory and Borland 1999). Accordingly, those who are unwilling or unable to cope with new market structures and risks choose the public sector as insurance.

\footnotetext{
${ }^{30}$ These results also hold when re-estimating these instrumental variable regressions using the cross-section from 2003 only or a more extended sample (see Table A 6 the Appendix). In only one case (cross-section, instrument 1, specification in Column 2) does the estimated coefficient become insignificant (p-value 0.156), but this loss in precision is probably due to the smaller sample size (in conjunction with generally larger 2SLS standard errors).
} 
What can be learned about the role of equalizing differentials in total compensation in post-Soviet Ukraine? Following the considerations in Section 2, the estimated satisfaction premium of state-sector employees indicates a larger fraction of unsatisfied workers in the private than in the public sector. Against the background of a continuously shrinking state sector, this satisfaction gap is indicative for an increasing "shortage" of public-sector jobs for which more and more private-sector workers queue as they would be better off. Hence, the satisfaction premium indeed represents a rent that one person receives by working in the state rather than the private sector. Reducing (increasing) total remuneration (monetary and nonmonetary) in the public (private) sector should lower the satisfaction differential.

\subsection{Sensitivity and robustness checks}

\subsubsection{Excluding recent privatizations}

The identifying assumption of the empirical strategy requires that the instrument (the ex-ante privatization probability) in itself does not directly affect today's job satisfaction (exclusion restriction). Although it is not possible to actually prove this condition, it is possible to provide suggestive evidence in support of the validity of the instruments. First, contrary to the general public notion that privatization hurts workers, Brown, Earle and Vakhitov (2006) and Brown, Earle and Telegdy (2010) show for Ukraine and other transition countries that privatization did not lead to job losses and had either only very small or no effects on wages (in fact, in some cases privatization even caused an increase in firm employment and wages). Second, managerial turnover (on higher management levels) that could potentially trigger unpleasant organizational change or a general restructuring of firms and thus might lower job satisfaction was actually less common in de novo or privatized firms than in state-owned enterprises (see Warzynski 2003 using a sample of 300 Ukrainian firms in 1997). Warzynski (2003) explains this finding by the fact that the particular privatization process in Ukraine predominantly led to insider ownership (by workers and managers). Third, general changes in the economic and political system during the transition process, e.g., more competitive pressure from foreign firms, liberalization of consumer prices, would affect all employees in Ukraine. Debardeleben (1999) analyses the attitudes of Russians towards the privatization process based on Russian survey data from 1993 to 1997. Individuals with personal privatization experiences are neither more nor less supportive of the privatization process and market liberalizations than persons without such personal privatization experience. The author concludes that disillusion with the political process and market 
transition as a whole led to a general negative assessment of single transition measures in the population. If similar mechanisms have taken place in Ukraine this would furthermore support the notion that privatization in itself did not affect satisfaction levels of individuals.

Additionally, it is possible to perform a simple test on whether the main estimation results are driven by recent - and possibly unpleasant - privatization experiences of some ULMS participants. If privatization has a direct negative effect on job satisfaction, this effect should be strongest immediately around or after the date of privatization and should gradually fade out over time. This is why the main G2SLS-RE regressions from Table 2 are repeated after dropping all observations that have experienced privatization within the last four years preceding the survey. Panel A in Table 3 indicates that the estimated state sector premium does not diminish after excluding these recent privatizations. ${ }^{31}$ In contrary, the estimates become even slightly larger thereby lending further support to the claim that the main regression results are not driven by possibly negative privatization experiences of workers.

\section{$<$ TABLE $3>>$}

\subsubsection{Excluding 'social Soviet jobs' and extreme IV values}

If Soviet workers actually could and did self-select into specific occupations and industries and if particular types of individuals (happy types) were attracted to 'typical Western' public sector jobs even in the Soviet Union (e.g., public administration, education, health) the validity of the instrumental variables would be in jeopardy. However, employees in the Soviet public administration, education or health care system (typically dominated by white-collar occupations) did not benefit from additional job amenities (like job security) which are typically attributed to public sector jobs in Western market economies. Hence, any self-selection of workers into 'typical' public sector industries on the basis of job characteristics which are commonly ascribed to Western public sector jobs (e.g. job amenities, job security) can be excluded. In fact, in the 1980s skilled manual workers received an official wage premium thereby earning more than managers and some professionals (Gerber and Hout 2004). Furthermore, Soviet workers in blue-collar occupations generally benefited from better working conditions and incentives - much in line with Soviet ideology and its emphasis on manual labor (Zajda 1980). This ideologically motivated preferential treatment of blue collar workers (i.e. not 'typical public sector' jobs) works against the idea that Soviet workers selected into 'typical public sector' industries due to beneficial job attributes.

\footnotetext{
${ }^{31}$ These results hold also when excluding only individuals having experienced privatization within the last, the last two or the last three years (results not reported).
} 
To find out whether the state sector satisfaction premium is merely caused by socially oriented personality types, Panel B of Table 3 presents results after excluding all individuals who used to work in 'typical social' jobs during the Soviet time. The problem with this approach is that it is theoretically possible that people enjoy doing social or service work and that this type of job content might actually represent job amenities leading to higher job satisfaction. Individuals are classified as 'Soviet social job' holders based on their Soviet 4digit ISCO occupational codes whenever these are related to education, health and safety services, social and social security workers (overall 58 different occupations). Excluding these observations from the sample tends to reduce the estimated public sector premium coefficient as well as the significance level slightly. However, the previous findings of a significantly positive job satisfaction premium of state sector workers are confirmed, suggesting that the positive effect of working in the public sector is not driven by socially oriented worker types.

Panel $\mathrm{C}$ of Table 3 shows that the results are also robust to excluding the smallest and largest values of the instrumental variables. By dropping the observations at the bottom and the top $5 \%$ of the instrumental variable distribution, this robustness checks makes sure that the main results are not driven by industries (and regions) with the lowest or the highest privatization probabilities (at the bottom these are education and public administration).

\subsubsection{Using only 'industry stayers'}

As the instrumental variables are assigned to workers' Soviet industry affiliations, they should be more powerful for individuals who remained in the same industry since Soviet times (workers might have changed jobs or firms within the same industry). Since this subsample of workers might generally differ from those workers who have switched industries, it is problematic to run the regression on this selected sample. Nevertheless, this exercise should help to test whether the instrument is 'functioning' in the right way, i.e. whether results become more precise despite a smaller sample size. The reassuring results in Panel D of Table 3 show that this is indeed the case: while the point estimates change slightly, the standard errors become smaller and the estimated coefficients are all highly significant. The first stage becomes stronger (results not shown).

\section{The Role of Fringe Benefits and Job Security}

If the state sector satisfaction premium is not caused by self-selection of workers, why are public sector workers on average more satisfied with their jobs? How important are 
differences in job amenities? The ULMS allows an assessment of the importance of two different types of amenity: perceived job security and fringe benefits.

The ULMS waves 2004 and 2007 contain a subjective measure of job security: Tell me, please, how satisfied are you with your current job in terms of job security? The five answer possibilities range from fully dissatisfied (=1) to fully satisfied (=5). Table 4 reports the effect of working in the state sector on satisfaction with job security. Across all specifications and instrumental variables the estimated effects are strikingly large (larger than in the job satisfaction regressions) and positively significant implying a substantial satisfaction premium in terms of job security in the state sector (even after correcting for selfselection into the public and private sector). The coefficients range between 0.54 and 0.90 of a standard deviation. These results seem to indicate that public sector jobs in the Ukraine are indeed perceived as more secure than private sector jobs and that this job facet might be a part of the overall public sector job satisfaction premium.

\section{$<$ TABLE $4>>$}

Regarding fringe benefits, the ULMS asks respondents a long battery of questions on provision of social benefits and financial incentive schemes by the employer. The question on social benefits is workplace rather than person specific: In this job do employees receive any of the following social benefits? Thus, part of the individual-level endogeneity problem (if benefit receipt within firms was heterogeneous) is alleviated, although it is still possible that workers sort into particular companies offering these types of job amenities. To reduce the dimensionality and complexity of the information, the 13 social benefits were grouped into three categories: social security (e.g., regular paid vacation, paid sick leave), subsidies (e.g., free childcare, discounted food, transportation or housing subsidies), and training (e.g., human-capital enhancing measures like paid training or payment for trips to sanatoria). The information on financial benefits is based on the question as to whether respondents received any amount of money in addition to their regular salary in the past year. Since receipt of this additional money is measured at the individual level, the problem of endogeneity is more pronounced. Three different types of payments are distinguished: non-performance-related benefits (i.e., $13^{\text {th }}$ salary), performance-related benefits (bonus payments or profit-sharing payment schemes), and risk compensation (compensation for non-normal work conditions).

A first descriptive analysis, set out in Table 5, demonstrates that both social benefits and financial benefits are much more common in the state than in the private sector. For instance, almost all state-sector (97 percent) but only 61 percent of private sector employees 
report that their workplace provides them with at least one of the following social security type of benefits: regular paid vacation, paid sick leave, paid maternity leave/childcare leave, and coverage of health-related expenses (or treatment in at the enterprise's clinic). The same pattern is found in the provision of training or subsidy type of benefits. It is important to note that these types of social benefits were generally available to all workers during the Soviet period-irrespective of their industry or occupation. Against this background, the post-Soviet discrepancy in provision of these benefits between both sectors is even more striking.

\section{$<$ TABLE $5>>$}

To analyze whether the estimated public job satisfaction premium can be explained by the variation in benefits across sectors, the GLS-RE and G2SLS-RE regressions from Section 4 are extended by successively including sets of dummy variables for different types of benefits (only social benefits, only financial benefits, both types of benefits). Several interesting findings emerge. First, adding controls for the provision of fringe benefits reduces the size of the estimated GLS-RE coefficients of the state sector dummy variable (Table 6, Columns 1 to 3 ). While the GLS-RE state-sector coefficient in the full regression specification was 0.211 , it drops to 0.141 once all types of benefits are included in the regression. In the GLS-RE regressions, the coefficients on social benefits as well as pay schemes show the expected positive sign and are significantly different from zero. However, despite the inclusion of these variables, there remains an unexplained positive satisfaction gap. Second, rerunning the regression with G2SLS-RE reveals the same pattern: the estimated coefficients drop in size, but remain significant. In summary, the public-private job satisfaction differential can be partly related to the different levels of social and financial fringe benefits in the two sectors. However, the explanatory power of these non-wage components of total compensation is limited, since two third of the public-sector premium remain even after controlling for these types of benefits.

$$
<\text { TABLE } 6>>
$$

\section{Conclusions}

This paper analyzes differences in job satisfaction between public- and private-sector employees. The main contribution is to disentangle the raw public-private sector satisfaction gap observed in Ukraine into a part reflecting self-selection of workers according to unobserved heterogeneity (i.e., personality types) and a remainder driven by genuine differences in job characteristics (i.e., rents in the public sector). This study is the first to 
address this particular problem using a natural experiment. The identification strategy exploits the quasi-experiment generated by the fundamental changes in ownership of enterprises made during Ukraine's transition to a market economy, during which workers were randomly reallocated from state- to private-sector jobs.

The empirical results reveal that the significantly positive public-sector satisfaction premium holds even after correcting for self-selection. Against the background of the theory of equalizing differentials, these results indicate rents received by public-sector employees in Ukraine. The findings are robust to several sensitivity tests. Accounting and correcting for the nonrandom sorting into state and private sector leads to an increase in the size of the satisfaction gap. This suggests a negative selection of workers into the public sector. An important conclusion of the analysis is that rents of public workers might be underestimated when not correcting for self-selection or when only looking at wages. The same pattern of negative selection is found for Germany using structural switching regression models (Luechinger, Stutzer, and Winkelmann 2010). However, the results are in contrast with those of Heywood et al. (2002), who find a positive selection into public-sector employment in the United Kingdom based on panel fixed effects estimations.

Assessing the potential drivers of the public-private satisfaction differential revealed that a certain fraction of the state-sector premium can be explained by different fringe benefits in the two sectors. However, as the significant public-sector satisfaction premium remains even after controlling for fringe benefits and self-selection, open questions remain regarding additional factors explaining the gap. These could include, for instance, sector differences in job and time flexibility (including formal as well as informal rules, e.g., specific firm culture and attitudes) or differences in wage compression across sectors, which would matter if individuals cared about wage inequality and relative wages within firms. Another explanation could be differences in perceived job and income uncertainty in the two sectors. In fact, the analysis revealed that public-sector employees are more satisfied with job security than their private-sector counterparts. In the absence of well-functioning financial markets, public-sector employment could act as an insurance mechanism and be thus especially valued by individuals (Rodrik 2000). Furthermore, public-sector rents could also be related to unofficial payments or bribes to public-sector employees. Indeed, Gorodnichenko and Sabirianova Peter (2007) point towards the existence of bribery in Ukraine. Having established the causality of the public-sector job satisfaction premium and having investigated one potential source of satisfaction difference (fringe benefits), this paper leaves the study of other job attributes which potentially drive the public-sector satisfaction premium for future research. 


\section{References}

Angrist, Joshua D. 2001. "Estimation of Limited Dependent Variable Models with Dummy Endogenous Regressors: Simple Strategies for Empirical Practice.” Journal of Business \& Economic Statistics, 19 (1): 2-16.

Ashenfelter, Orley. 1978. "Estimating the Effect of Training Programs on Earnings." Review of Economics and Statistics, 60 (1): 47-57.

Belfield, Clive R. and R.D.F. Harris. 2002. "How Well Do Theories of Job Matching Explain Variations in Job Satisfaction Across Education Levels? Evidence for UK Graduates." Applied Economics, 34 (5): 535-548.

Blank, Rebecca M. 1985. “An Analysis of Workers' Choice Between Employment in the Public and Private Sectors.” Industrial and Labor Relations Review, 38 (2): 211-224.

Boswell, Wendy R., John W. Boudreau, and Jan Tichy. 2005. “The Relationship Between Employee Job Change and Job Satisfaction: The Honeymoon-Hangover Effect.” Journal of Applied Psychology, 90 (5): 882-892.

Brown, David J., John S. Earle, and Álmos Telegdy. 2006. “The Productivity Effects of Privatization: Longitudinal Estimates from Hungary, Romania, Russia and Ukraine." Journal of Political Economy, 114 (2): 61-99.

Brown, David J., John S. Earle, and Álmos Telegdy. 2010. "Employment and Wage Effects of Privatisation: Evidence from Hungary, Romania, Russia and Ukraine." Economic Journal, 120 (545): 683-708.

Brown, David J., John S. Earle, and Volodymyr Vakhitov. 2006. "Wages, Layoffs, and Privatization: Evidence from Ukraine.” Journal of Comparative Economics, 34 (2): 272-294.

Brown, Emily Clark. 1973. "Fundamental Soviet Labor Legislation.” Industrial and Labor Relations Review, 26 (2): 778-792.

Clark, Andrew. 1997. "Job Satisfaction and Gender: Why Are Women So Happy at Work?" Labour Economics, 4 (4): 341-372.

Clark, Andrew E., Ed Diener, Yannis Georgellis, and Richard E. Lucas. 2008. "Lags and Leads in Life Satisfaction: A Test of the Baseline Hypothesis." Economic Journal, 118 (529): F222-F243. 
Clark, Andrew E., Paul Frijters, and Michael A. Shields. 2008. "Relative Income, Happiness, and Utility: An Explanation for the Easterlin Paradox and Other Puzzles.” Journal of Economic Literature, 46 (1): 95-144.

Clark, Andrew E. and Andrew J. Oswald. 1996. "Satisfaction and Comparison Income." Journal of Public Economics, 61 (3): 359-381.

Clark, Andrew E. and Claudia Senik. 2006. "The (Unexpected) Structure of 'Rents' on the French and British Labour Markets.” Journal of Socio-Economics, 35 (2): 180-196.

Danzer, Alexander M. and Peter J. Dolton. 2012. "Total Reward and Pensions in the UK in the Public and Private Sectors." Labour Economics, 19 (4): 584-594.

Demoussis, Michael and Nicholas Giannakopoulos. 2007. "Exploring Job Satisfaction in Private and Public Employment: Empirical Evidence from Greece.” Labour, 21 (2): $333-359$.

Ehrenberg, Ronald G. and Joshua L. Schwarz. 1987."Public Sector Labor Markets.” In: Ashenfelter, Orley C. and Richard Layard (eds.), Handbook of Labor Economics, Elsevier, Volume 2, part 2, chapter 22: 1219-1260.

Estrin, Saul, Jan Hanousek, Evzen Kocenda, and Jan Svejnar. 2009. "The Effects of Privatization and Ownership in Transition Economies." Journal of Economic Literature, 47 (3): 699-728.

Ferrer-i-Carbonell, Ada and Paul Frijters. 2004."How Important is Methodology for the Estimates of the Determinants of Happiness?" Economic Journal, 114 (497): 641-659.

Flemming, John S. and John Micklewright. 2000. "Income Distribution, Economic Systems and Transition.” In: Atkinson, Anthony B. and Francois Bourguignon (eds.), Handbook of Income Distribution, Elsevier, volume 1, chapter 14: 843-918.

Friebel, Guido and Sergei Guriev. 2005. "Attaching Workers Through In-Kind Payments: Theory and Evidence from Russia.” World Bank Economic Review, 19 (2): 175-202.

Frijters, Paul, Ingo Geishecker, John Haisken-DeNew, and Michael A. Shields. 2006. "Can the Large Swings in Russian Life Satisfaction be Explained by Ups and Downs in Real Incomes?” Scandinavian Journal of Economics, 108 (3): 433-458.

Fuchs-Schündeln, Nicola and Matthias Schündeln. 2005."Precautionary Savings and SelfSelection: Evidence from the German Reunification 'Experiment'." Quarterly Journal of Economics, 120 (3): 1085-1120. 
Ganguli, Ina and Katherine Terrell. 2006. “Institutions, Markets and Men's and Women's Wage Inequality: Evidence from Ukraine.” Journal of Comparative Economics, 34 (2): 200-227.

Ghinetti, Paolo. 2007. “The Public-Private Job Satisfaction Differential in Italy.” Labour, 21 (2): $361-388$.

Gibbons, Robert and Lawrence F. Katz. 1992. "Does Unmeasured Ability Explain InterIndustry Wage Differentials?” Review of Economic Studies, 59 (3): 515-535.

Gorodnichenko, Yurij and Klara Sabirianova Peter. 2007. "Public Sector Pay and Corruption: Measuring Bribery from Micro Data.” Journal of Public Economics, 91 (5-6): 963-991.

Gregory, Paul R. and Irwin L. Collier. 1988. "Unemployment in the Soviet Union: Evidence from the Soviet Interview Project.” American Economic Review, 78 (4): 613-632.

Gregory, Paul R. and Janet E. Kohlhase. 1988. "The Earnings of Soviet Workers: Evidence from the Soviet Interview Project." Review of Economics and Statistics, 70 (1): 23-35.

Gregory, Robert G. and Jeff Borland. 1999. "Recent Developments in Public Sector Markets.” In: Ashenfelter, Orley C. and David Card (eds.), Handbook of Labor Economics, Elsevier, volume 3, part 3, chapter 53: 3573-3630.

Grygorenko, Galyna and Stefan Lutz. 2007. "Firm Performance and Privatization in Ukraine." Economic Change and Restructuring, 40 (3):253-266.

Haddad, L. 1972. "Wages in the Soviet Union: Problems of Policy." Journal of Industrial Relations, 14 (2): 171-174.

Hamermesh, Daniel S. 1999. "Changing Inequality in Markets for Workplace Amenities." Quarterly Journal of Economics, 114 (4): 1085-1123.

Hamermesh, Daniel S. 2001."The Changing Distribution of Job Satisfaction.” Journal of Human Resources, 36 (1): 1-30.

Helliwell, John and Haifang Huang. 2010. "How's the Job? Well-Being and Social Capital in the Workplace." Industrial and Labor Relations Review, 63(2): Article 2.

Heywood, John S., W. S. Siebert, and Xiangdong Wei. 2002. "Worker Sorting and Job Satisfaction: The Case of Union and Government Jobs." Industrial and Labor Relations Review, 55(4): 595-609. 
Imbens, Guido W. and Joshua D. Angrist. 1994. "Identification and Estimation of Local Average Treatment Effects." Econometrica, 62 (2): 467-475.

Katz, Lawrence F. and David H. Autor. 1999. "Changes in the Wage Structure and Earnings Inequality.” In: Card, David (ed.), Handbook of Labor Economics, Elsevier, volume 3A, 1463-1555.

Krueger, Alan B. 1988. “The Determinants of Queues for Federal Jobs.” Industrial and Labor Relations Review, 41(4): 567-581.

Luechinger, Simon, Stephan Meier, and Alois Stutzer. 2008. "Bureaucratic Rents and Life Satisfaction.” Journal of Law, Economics, and Organization, 24 (2): 476-488.

Luechinger, Simon, Stephan Meier, and Alois Stutzer. 2010. "Why Does Unemployment Hurt the Employed? Evidence from the Life Satisfaction Gap Between the Public and the Private Sector.” Journal of Human Resources, 45 (4): 998-1045.

Luechinger, Simon, Alois Stutzer, and Rainer Winkelmann. 2006. "The Happiness Gains from Sorting and Matching in the Labor Market.” IZA discussion paper, No. 2019.

Luechinger, Simon, Alois Stutzer, and Rainer Winkelmann. 2010. "Self-Selection Models for Public and Private Sector Job Satisfaction." Research in Labor Economics, 30 (30): 233-251.

Megginson, William L. and Jeffry M. Netter. 2001. "From State to Market: A Survey of Empirical Studies on Privatization.” Journal of Economic Literature, 39 (2): 321-389.

Pivovarsky, Alexander. 2001. "How Does Privatization Work? Ownership Concentration and Enterprise Performance in Ukraine.” IMF working paper, No. WP/01/42.

Rodrik, Dani. 2000. “What Drives Public Employment in Developing Countries?” Review of Development Economics, 4 (3): 229-243.

Rosen, Sherwin. 1987. “The Theory of Equalizing Differences.” In: Ashenfelter, Orley C. and Richard Layard (eds.), Handbook of Labor Economics, Elsevier, edition 1, volume 1, part 1, chapter 12: 641-692.

Senik, Claudia. 2004. "When Information Dominates Comparison-Learning from Russian Subjective Panel Data.” Journal of Public Economics, 88 (9-10): 2099-2123.

State Statistics Committee of Ukraine. 2005. Statistical Yearbook of Ukraine 2004. Kiev, Ukraine. 
Stock, James H., Jonathan H. Wright, and Motohiro Yogo. 2002. “A Survey of Weak Instruments and Weak Identification in Generalized Method of Moments." Journal of Business and Economic Statistics, 20 (4): 518-529.

Titma, Mikk and Ave Roots. 2006. "Intragenerational Mobility in Successor States of the USSR.” European Societies, 8 (4): 493-526.

USAID. 1999.“Final Report. Ukraine Mass Privatization Project.” Report prepared by PricewaterhouseCoopers. Available at: http://pdf.usaid.gov/pdf_docs/PDABR432.pdf

USAID. 2000. “History of Privatisation of Ukraine's Energy Companies.” Report available at: http://pdf.usaid.gov/pdf_docs/Pnack605.pdf

Vieira, José A. Cabral. 2005. "Skill Mismatches and Job Satisfaction.” Economics Letters, 89 (1): 39-47. 


\section{Figure 1. Evolution of share of employment in the state sector}

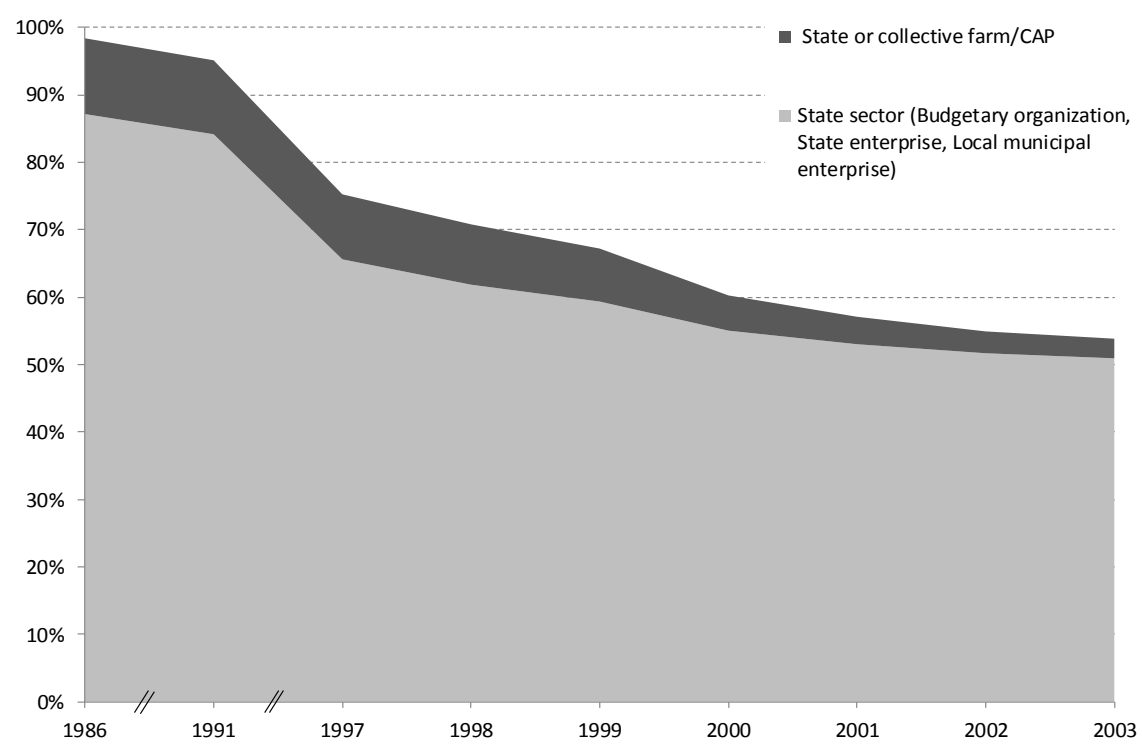

Source: Ukrainian Longitudinal Monitoring Survey (ULMS) 2003; own calculations $(N=7,058)$.

Figure 2. Reasons for termination of jobs, by industrial sector 1986 (\%)



Source: ULMS 2003; own calculations based retrospective job histories $(N=4,650)$. 
Figure 3. Job satisfaction in the private and public sector in Ukraine

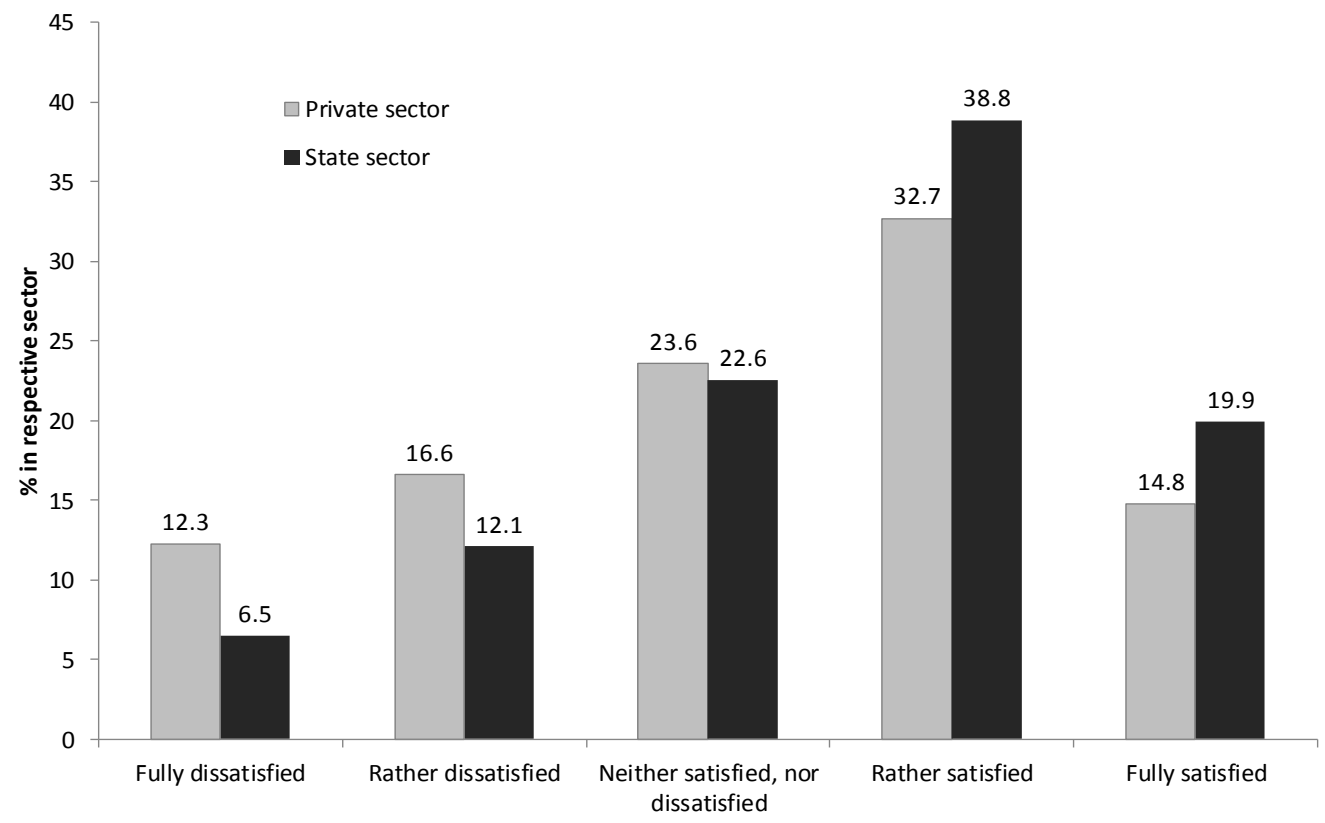

Source: ULMS 2003-2007, pooled sample of all individuals of working age with retrospective Soviet job information (extended regression sample; $N=5,142$ ); own calculations. 


\section{Figure 4. Illustration of the two instrumental variables}

\section{Instrumental Variable 1 (Privatization Probability)}

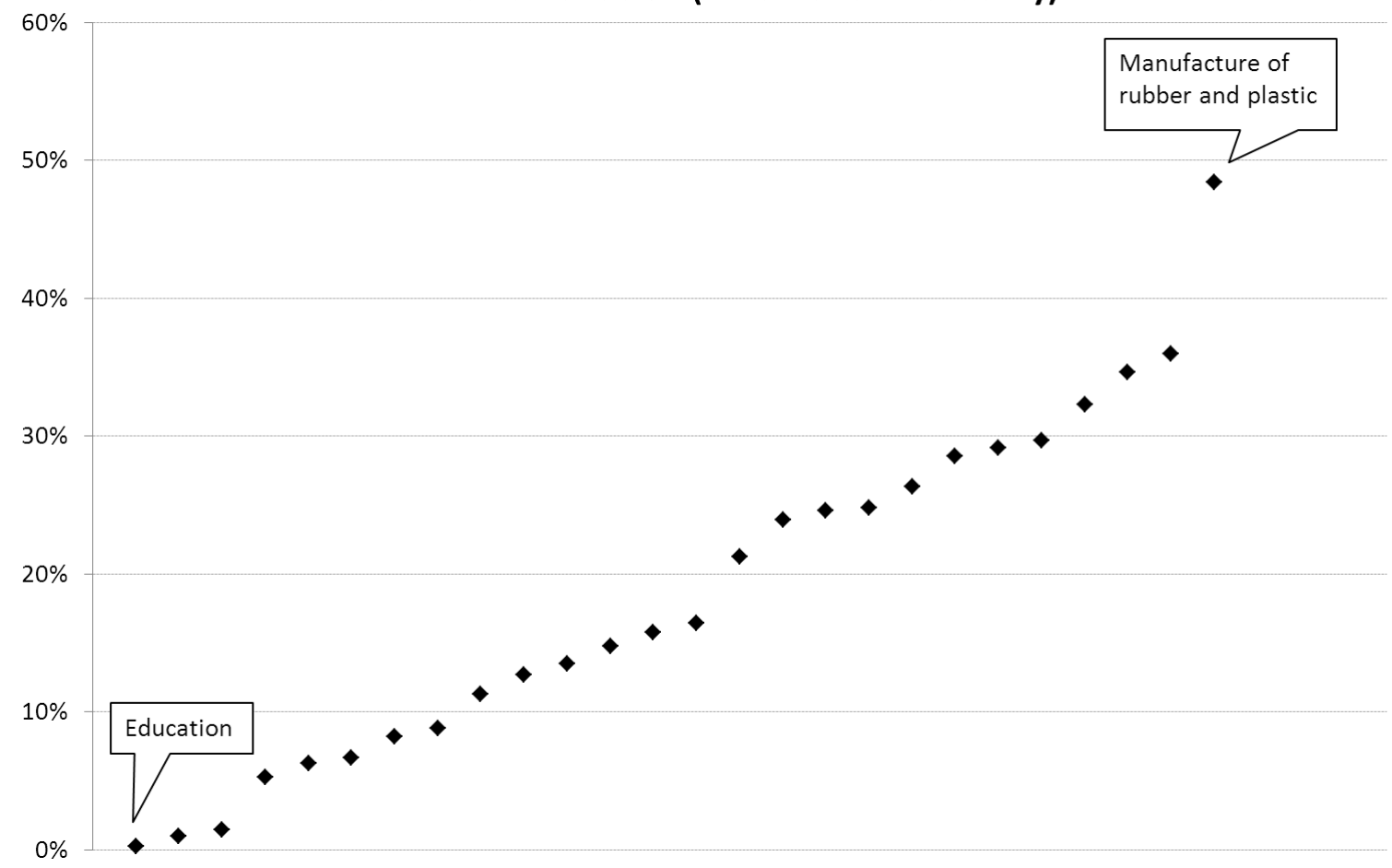

Instrumental Variable 2 (Private Sector Share)

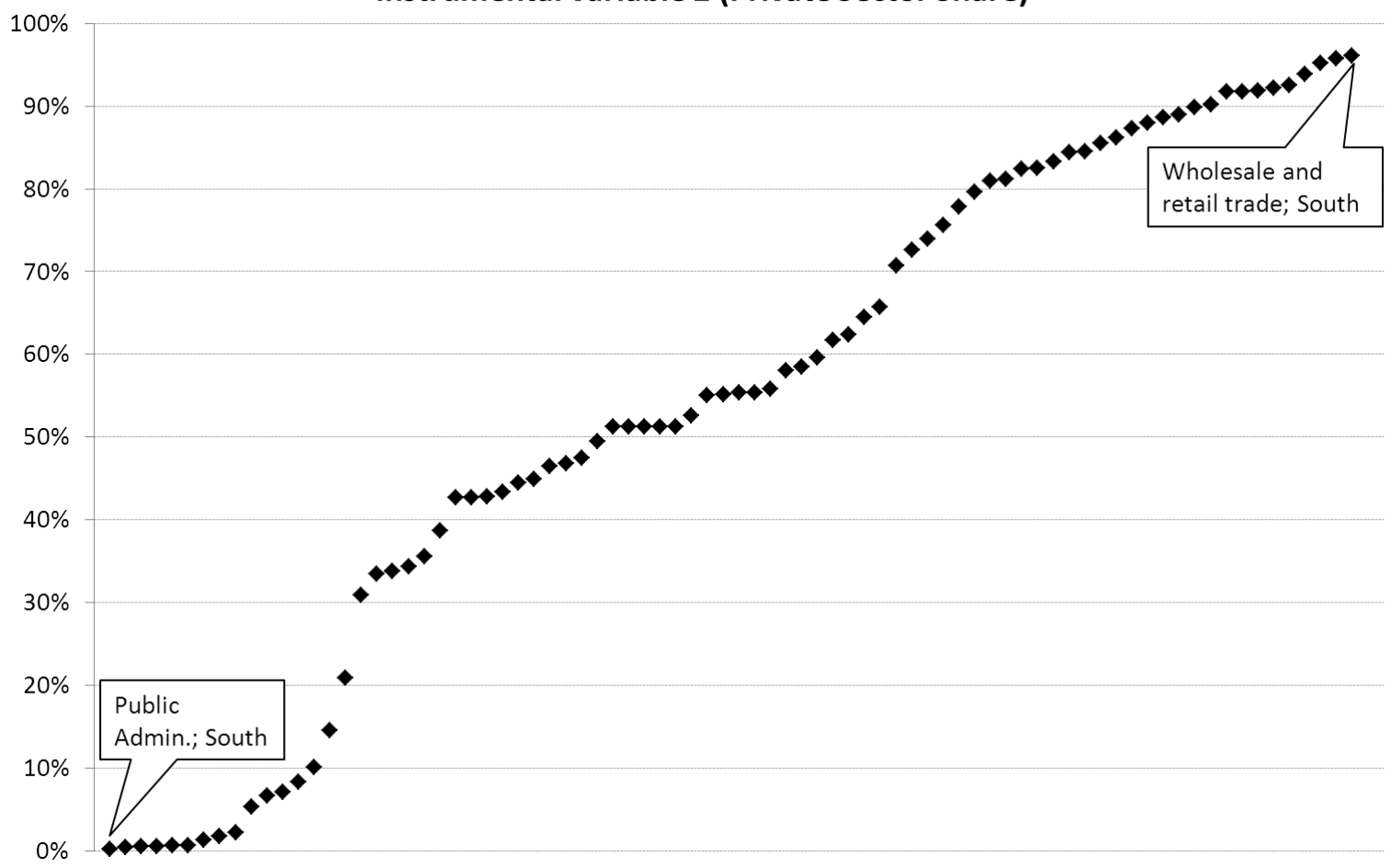

Notes: Instrumental variable 1 captures the ex-ante privatization probability for 27 different industries (calculated using the retrospective ULMS data). Instrumental variable 2 reflects the current post-Soviet share of private sector jobs in 80 industryregion cells (based on UHBS data 2003 - 2006; $\mathrm{N}=34,344$ ). 
Table 1: Job satisfaction regressions with step-wise inclusion of covariates (GLS-RE estimates; selected coefficients)

Dependent variable: Job satisfaction

(1) (2) (3) (4)

\begin{tabular}{|c|c|c|c|c|}
\hline State sector & $\begin{array}{l}0.340 * * * \\
(0.043)\end{array}$ & $\begin{array}{c}0.277 * * * \\
(0.042)\end{array}$ & $\begin{array}{c}0.266 * * * \\
(0.043)\end{array}$ & $\begin{array}{c}0.212 * * * \\
(0.041)\end{array}$ \\
\hline Male & & $\begin{array}{l}-0.064 \\
(0.062)\end{array}$ & $\begin{array}{l}-0.035 \\
(0.066)\end{array}$ & $\begin{array}{l}-0.133^{*} \\
(0.076)\end{array}$ \\
\hline General secondary educ. & & $\begin{array}{c}0.026 \\
(0.076)\end{array}$ & $\begin{array}{c}0.028 \\
(0.076)\end{array}$ & $\begin{array}{l}-0.001 \\
(0.075)\end{array}$ \\
\hline Professional sec. educ. & & $\begin{array}{c}0.197 * * \\
(0.081)\end{array}$ & $\begin{array}{c}0.130 \\
(0.083)\end{array}$ & $\begin{array}{c}0.004 \\
(0.084)\end{array}$ \\
\hline Higher education & & $\begin{array}{l}0.413 * * * \\
(0.088)\end{array}$ & $\begin{array}{l}0.282 * * * \\
(0.094)\end{array}$ & $\begin{array}{c}0.014 \\
(0.101)\end{array}$ \\
\hline Professional occupation & & & & $\begin{array}{c}0.417 * * * \\
(0.078)\end{array}$ \\
\hline Technical occupation & & & & $\begin{array}{c}0.364 * * * \\
(0.073)\end{array}$ \\
\hline Skilled blue-collar occ. & & & & $\begin{array}{c}0.142 * * * \\
(0.053)\end{array}$ \\
\hline Less than 31 hours & & & & $\begin{array}{c}-0.198 * * * \\
(0.065)\end{array}$ \\
\hline More than 50 hours & & & & $\begin{array}{l}-0.081 \\
(0.063)\end{array}$ \\
\hline Medium-sized firm & & & & $\begin{array}{l}0.080 \\
(0.056)\end{array}$ \\
\hline Large-sized firm & & & & $\begin{array}{c}0.049 \\
(0.057)\end{array}$ \\
\hline Log earnings & & & & $\begin{array}{c}0.394 * * * \\
(0.048)\end{array}$ \\
\hline Log avg. industry wage & & & & $\begin{array}{c}0.176^{* *} \\
(0.074)\end{array}$ \\
\hline Weekend work & & & & $\begin{array}{c}-0.080 * * \\
(0.039)\end{array}$ \\
\hline Shift work & & & & $\begin{array}{l}0.063 \\
(0.053)\end{array}$ \\
\hline Extrovert & & & & $\begin{array}{l}0.078^{*} \\
(0.047)\end{array}$ \\
\hline Neurotic & & & & $\begin{array}{l}-0.154 \\
(0.106)\end{array}$ \\
\hline Risk loving & & & & $\begin{array}{c}0.027 \\
(0.052)\end{array}$ \\
\hline Constant & $\begin{array}{c}3.029 * * * \\
(0.058)\end{array}$ & $\begin{array}{c}2.222 * * * \\
(0.621)\end{array}$ & $\begin{array}{c}2.522 * * * \\
(0.885)\end{array}$ & $\begin{array}{l}-1.522 \\
(0.961)\end{array}$ \\
\hline Chi-squared & 194.7 & 475.1 & 504.8 & 870.9 \\
\hline $\begin{array}{l}\text { Gender, age, family background, } \\
\text { marital status, health, region }\end{array}$ & - & $\checkmark$ & $\checkmark$ & $\checkmark$ \\
\hline Soviet period controls & - & - & $\checkmark$ & $\checkmark$ \\
\hline$R$-squared overall & 0.0430 & 0.106 & 0.112 & 0.187 \\
\hline
\end{tabular}

Notes: The table reports selected coefficients (for full set of estimated coefficients and additional regression specifications, see Appendix, Error! Reference source not found.). All regressions control for interview year and month fixed effects. Omitted categories: "primary education," "occupation: unskilled," "working hours: 31 to 50 hours," "small-sized firm." Number of observations 4,191 (number of id: 1,915). Standard errors are clustered on the individual level. Robust standard errors are shown in parentheses. $* * * \mathrm{p}<0.01, * * \mathrm{p}<0.05, *$ p $<0.1$; Source: ULMS 2003-2007; own calculations. 
Table 2: Regression results (GLS-RE, G2SLS-RE, reduced form, first stage)

Instrumental variable 1:

Privatization probability

(1) (2) (3)

A. GLS-RE

State sector

B. G2SLS-RE

State sector

C. GLS-RE Reduced Form

Instrumental variable

D. GLS-RE First Stage

Instrumental variable

Z statistic

Chi $^{2}$ statistic $^{\text {A) }}$
DV: Job satisfaction

$$
\begin{array}{ccc}
0.340^{* * * *} & 0.266^{* * * *} & 0.212^{* * *} \\
(0.043) & (0.043) & (0.041)
\end{array}
$$

DV: Job satisfaction

$0.687 * * * \quad 0.398 * * \quad 0.488^{* * *} *$

$\begin{array}{lll}(0.160) & (0.187) \quad(0.185)\end{array}$

DV: Job satisfaction

$-0.827 * * *-0.422 * * \quad-0.504 * * *$

$\begin{array}{lll}(0.187) & (0.189) & (0.179)\end{array}$

DV: State sector (binary variable)

$-1.207 * * *-1.070 * * *-1.036 * * *$

$\begin{array}{lll}(0.070) & (0.074) & (0.071)\end{array}$

$\begin{array}{lll}-17.18 & -14.40 & -14.64\end{array}$

$\begin{array}{lll}161.1 & 101.7 & 111.7\end{array}$
Instrumental variable 2:

Private-sector share

(4) (5) (6)

DV: Job satisfaction

$0.340 * * * \quad 0.266 * * * \quad 0.212 * * *$

$\begin{array}{lll}(0.043) & (0.043) & (0.041)\end{array}$

DV: Job satisfaction

$0.940 * * * 0.567 * * * 0.519 * * *$

(0.131) (0.146)

(0.159)

Socio-demographic post-Soviet \& Soviet characteristics

Current job \& firm

characteristics (incl. earnings)

Personality traits, risk aversion

Observations

$4,191 \quad 4,191 \quad 4,191$

DV: Job satisfaction

$-0.475 * * *-0.261 * * *-0.210 * * *$

$(0.063) \quad(0.067)$

(0.064)

DV: State sector (binary variable)

$-0.504 * * *-0.461 * * *-0.405 * * *$

$(0.023) \quad(0.025) \quad(0.023)$

$\begin{array}{lll}-22.08 & -18.84 & -17.28\end{array}$

$290.9 \quad 187.9 \quad 173.6$

Notes: Dependent variable (DV) in A.-C.: Job satisfaction. DV in panel D.: State sector (binary variable). The table reports only the estimated coefficients of interest (state sector; instrumental variables) from the following regression specifications: Columns 1 and 4 correspond to the specification in Table 1, Column 1; Columns 2 and 5 correspond to Table 1, Column 3; Columns 3 and 6 correspond to Table 1, Column 4. ${ }^{\text {A) }}$ The chi-squared test statistic from the weak instrument test in the first-stage regression is calculated from a separate first-stage regression in which results differ slightly from the first-stage results based on the Stata build-in xtivreg command (reported coefficient and z statistic in the table above). However, the chi-squared test statistic cannot be computed using the xtivreg command. Standard errors are clustered on the individual level; robust standard errors are shown in parentheses; $* * * \mathrm{p}<0.01, * * \mathrm{p}<0.05, * \mathrm{p}<0.1$; Source: ULMS 2003-2007; own calculations. 
Table 3: Sensitivity and robustness checks: Instrumental variable estimates (G2SLS-RE)

Instrumental variable 1:

Privatization probability

\section{(1)}

(2)

Job satisfaction
(3)
Instrumental variable 2:

Private sector share
(5)

(6)

Dependent variable:

(4)

Job satisfaction

Original G2SLS-RE regression results (Table 2; $N=4,191$ )

$\begin{array}{lcccccc}\text { State sector } & 0.687 * * * & 0.398 * * & 0.488^{* * *} & 0.940 * * * & 0.567 * * * & 0.519 * * * \\ & (0.160) & (0.187) & (0.185) & (0.131) & (0.146) & (0.159)\end{array}$

Sensitivity and robustness checks

\section{A. Excluding privatizations in last 4 years $(N=4,134)$}

$\begin{array}{lcccccc}\text { State sector } & 0.708^{* * *} & 0.435^{* *} & 0.513^{* * *} & 0.947 * * * & 0.580^{* * *} & 0.526^{* * *} \\ & (0.161) & (0.189) & (0.190) & (0.133) & (0.148) & (0.163) \\ & & & & & \\ \text { B. Excluding 'Soviet social jobs' }(\boldsymbol{N}=3,465) & & & & & \\ \text { State sector } & 0.384 & 0.459^{*} & 0.461^{* *} & 0.864 * * * & 0.663 * * * & 0.484^{* *} \\ & (0.262) & (0.263) & (0.231) & (0.194) & (0.199) & (0.198)\end{array}$

C. Excluding extreme instrumental variable values $\left(N=3,466(\text { IV 1); } N=3,725 \text { (IV 2) })^{A)}\right.$
State sector$$
0.817 * * * \quad 0.683 * * * \quad 0.689 * * *
$$$$
0.940 * * * \quad 0.624 * * *
$$
$(0.246)$
$(0.241)$
$(0.133)$
$(0.151)$
$(0.160)$

D. Using only industry stayers $(N=2,431)$
State sector
$0.518 * * *$
$0.329 * *$
$0.446^{* * *}$
$0.802 * * *$
$0.575 * * *$
$0.574 * * *$
$(0.135)$
$(0.156)$
$(0.144)$
$(0.109)$
$(0.122)$
$(0.123)$

Socio-demographic Post-Soviet and Soviet characteristics

Current job and firm characteristic (incl. earnings)

Personality traits, risk aversion

Notes: Dependent variable: Five-point Likert scale of job satisfaction with 1 (fully dissatisfied) to 5 (fully satisfied). The table reports only the estimated coefficients of interest (state sector; instrumental variables) from the following regression specifications: columns (1) and (4) correspond to the specification in Table 1, column (1); columns (2) and (5) correspond to Table 1, column (3); columns (3) and (6) correspond to Table 1, column (8). ${ }^{\text {A) }}$ The sample is censored at the top and bottom $5 \%$ with respect to the IV values. Standard errors are clustered on the individual level; robust standard errors are shown in parentheses; *** $\mathrm{p}<0.01, * * \mathrm{p}<0.05$, * p $<0.1$; Source: ULMS 2003-2007; own calculations. 


\section{Table 4: Regression results on satisfaction with job security (G2SLS-RE)}

Instrumental variable 1:

Privatization probability

\section{(1)}

(2)

$0.923 * * *$

$0.746^{* * * *}$

(3)

State sector
Instrumental variable 2:

Private sector share

\author{
(4)
}

(5)

(6)

Socio-demographic Post-Soviet

and Soviet characteristics

Current job and firm

characteristic (incl. earnings)

Personality traits, risk aversion

Notes: Dependent variable: Five-point Likert scale of 'satisfaction with job in terms of job security' (1=fully dissatisfied to $5=$ fully satisfied). The table reports only the estimated coefficients of interest (state sector; instrumental variables) from the following regression specifications: columns (1) and (4) correspond to the specification in Table 1, column (1); columns (2) and (5) correspond to Table 1, column (3); columns (3) and (6) correspond to Table 1, column (8). This satisfaction question was only asked in the survey years 2004 and 2007. Standard errors are clustered on the individual level; robust standard errors are shown in parentheses; *** $\mathrm{p}<0.01, * * \mathrm{p}<0.05, * \mathrm{p}<0.1$; Source: ULMS 2003-2007 $(\mathrm{N}=2,448)$; own calculations.

Table 5: Incidence and differences in social benefits and payment incentive schemes between private and state sectors

\begin{tabular}{|c|c|c|c|c|}
\hline Variable & $\begin{array}{c}\text { Private sector } \\
(1) \\
\text { Mean }\end{array}$ & $\begin{array}{c}\text { State sector } \\
(2) \\
\text { Mean }\end{array}$ & $\begin{array}{c}\text { Difference } \\
(1)-(2)\end{array}$ & t statistic \\
\hline \multicolumn{5}{|l|}{ Social benefits } \\
\hline SB: Social security & 0.63 & 0.97 & $-0.34 * * *$ & -30.90 \\
\hline SB: Subsidies & 0.17 & 0.33 & $-0.16 * * *$ & -11.74 \\
\hline SB: Training & 0.11 & 0.28 & $-0.17 * * *$ & -14.12 \\
\hline \multicolumn{5}{|l|}{ Financial incentive pay scheme } \\
\hline FB: Non-performance related & 0.06 & 0.14 & $-0.08 * * *$ & -9.03 \\
\hline FB: Performance related & 0.18 & 0.27 & $-0.10 * * *$ & -7.38 \\
\hline FB: Risk compensation & 0.02 & 0.06 & $-0.03 * * *$ & -5.55 \\
\hline
\end{tabular}

Source: ULMS 2003-2007; own calculations. Number of observations: 2,035 (private sector), 2,156 (state sector). Pooled sample of all individuals of working age at time of interview with full information on all variables, who were 16 or older in December 1991, and for whom there is information on their job during the Soviet time (December 1986 or December 1991). Reported $\mathrm{t}$ statistics refer to mean comparison tests between state and private sectors. 
Table 6: The role of fringe benefits; GLS-RE and G2SLS-RE estimates; dependent variable: job satisfaction

\begin{tabular}{|c|c|c|c|c|c|c|c|c|c|}
\hline & (1) & (2) & (3) & (4) & (5) & (6) & (7) & (8) & (9) \\
\hline & \multicolumn{3}{|c|}{ GLS-RE } & \multicolumn{3}{|c|}{$\begin{array}{c}\text { G2SLS-RE, IV 1: } \\
\text { Privatization } \\
\text { probability }\end{array}$} & \multicolumn{3}{|c|}{$\begin{array}{l}\text { G2SLS-RE, IV 2: } \\
\text { Private-sector share }\end{array}$} \\
\hline State sector & $\begin{array}{c}0.153 * * * \\
(0.044)\end{array}$ & $\begin{array}{c}0.188 * * * \\
(0.042)\end{array}$ & $\begin{array}{c}0.140^{* * * *} \\
(0.044)\end{array}$ & $\begin{array}{c}0.453^{* *} \\
(0.201)\end{array}$ & $\begin{array}{c}0.472 * * \\
(0.188)\end{array}$ & $\begin{array}{c}0.452^{* *} \\
(0.202)\end{array}$ & $\begin{array}{c}0.482 * * * \\
(0.171)\end{array}$ & $\begin{array}{c}0.498^{* * * *} \\
(0.163)\end{array}$ & $\begin{array}{c}0.472 * * * \\
(0.172)\end{array}$ \\
\hline \multicolumn{10}{|l|}{ Social benefits } \\
\hline Social security & $\begin{array}{c}0.164 * * * \\
(0.060)\end{array}$ & & $\begin{array}{c}0.148 * * \\
(0.060)\end{array}$ & $\begin{array}{c}0.058 \\
(0.090)\end{array}$ & & $\begin{array}{c}0.040 \\
(0.090)\end{array}$ & $\begin{array}{l}0.048 \\
(0.082)\end{array}$ & & $\begin{array}{c}0.033 \\
(0.082)\end{array}$ \\
\hline Subsidies & $\begin{array}{l}0.073^{*} \\
(0.044)\end{array}$ & & $\begin{array}{l}0.054 \\
(0.044)\end{array}$ & $\begin{array}{c}0.058 \\
(0.045)\end{array}$ & & $\begin{array}{c}0.041 \\
(0.045)\end{array}$ & $\begin{array}{l}0.057 \\
(0.045)\end{array}$ & & $\begin{array}{c}0.041 \\
(0.045)\end{array}$ \\
\hline Training & $\begin{array}{c}0.141^{* * *} * \\
(0.046)\end{array}$ & & $\begin{array}{l}0.118^{* * *} \\
(0.047)\end{array}$ & $\begin{array}{c}0.113 * * \\
(0.051)\end{array}$ & & $\begin{array}{l}0.093 * \\
(0.050)\end{array}$ & $\begin{array}{c}0.110^{* *} \\
(0.050)\end{array}$ & & $\begin{array}{l}0.091^{*} \\
(0.049)\end{array}$ \\
\hline \multicolumn{10}{|l|}{ Financial benefits } \\
\hline Non-performance rel. & & $\begin{array}{c}0.152 * * * \\
(0.058)\end{array}$ & $\begin{array}{c}0.125 * * \\
(0.058)\end{array}$ & & $\begin{array}{l}0.113^{*} \\
(0.065)\end{array}$ & $\begin{array}{c}0.095 \\
(0.063)\end{array}$ & & $\begin{array}{l}0.110^{*} \\
(0.063)\end{array}$ & $\begin{array}{c}0.093 \\
(0.062)\end{array}$ \\
\hline Performance related & & $\begin{array}{c}0.157 * * * \\
(0.042)\end{array}$ & $\begin{array}{c}0.136 * * * \\
(0.042)\end{array}$ & & $\begin{array}{c}0.146 * * * \\
(0.043)\end{array}$ & $\begin{array}{c}0.134 * * * \\
(0.043)\end{array}$ & & $\begin{array}{c}0.145^{* * * *} \\
(0.043)\end{array}$ & $\begin{array}{c}0.134 * * * \\
(0.043)\end{array}$ \\
\hline Risk compensation & & $\begin{array}{l}0.157^{*} \\
(0.082)\end{array}$ & $\begin{array}{l}0.135^{*} \\
(0.082)\end{array}$ & & $\begin{array}{c}0.120 \\
(0.089)\end{array}$ & $\begin{array}{c}0.102 \\
(0.089)\end{array}$ & & $\begin{array}{c}0.117 \\
(0.088)\end{array}$ & $\begin{array}{c}0.100 \\
(0.088)\end{array}$ \\
\hline Observations & 4,191 & 4,191 & 4,191 & 4,191 & 4,191 & 4,191 & 4,191 & 4,191 & 4,191 \\
\hline Full set of controls & $\checkmark$ & $\checkmark$ & $\checkmark$ & $\checkmark$ & $\checkmark$ & $\checkmark$ & $\checkmark$ & $\checkmark$ & $\checkmark$ \\
\hline
\end{tabular}




\section{(ONLINE) APPENDIX}

Job Satisfaction and Self-Selection into the Public or Private Sector:

Evidence from a Natural Experiment

Natalia Danzer

Ifo Institute, University of Munich (LMU),

and IZA Bonn, Germany

danzer@ifo.de 


\section{Appendix A. Additional Tables}

\section{Table A 1: Overview on final sample size and labor market composition of original sample}

Cross section 2003

Absolute Percentage
numbers

Information on final sample size

Total sample

$100.0 \%$

Working ${ }^{\text {A) }}$

out of which

have reached legal minimum working age in 1991

2,943

AND held a job in Dec. 1986 and/or Dec. 1991

2,556

AND have complete information in included variables:

\section{Main regression sample with full set of controls $\quad 1,491$ \\ II. Extended regression sample (excl. variables with many $\quad 2,059$ missings; used for robustness tests)}

Unemployed, ILO

Out of labor force/student, working age

Out of labor force, pension age

Out of labor force, other

354

Source: ULMS 2003; own calculations. ${ }^{\mathrm{A})}$ In official working age (younger than official pension age).

\section{Table A 2: Variable definition}

\begin{tabular}{|c|c|}
\hline Variable name & Variable definition \\
\hline \multicolumn{2}{|l|}{ Satisfaction measures } \\
\hline Job satisfaction & $\begin{array}{l}\text { Job Satisfaction based on the question: Tell me, please, how satisfied are you } \\
\text { with your current job? Answer option: } 1 \text { Fully dissatisfied/ } 2 \text { Rather } \\
\text { dissatisfied/ } 3 \text { Neither satisfied, nor dissatisfied/ } 4 \text { Rather satisfied/ } 5 \text { Fully } \\
\text { satisfied (This is the author's translation of the Russian and Ukrainian } \\
\text { questionnaire. The English version of these answers provided by the survey } \\
\text { institute KIIS is 1-not satisfied at all, 2-less than satisfied, 3-rather } \\
\text { satisfied, 4-satisfied, and 5-fully satisfied, which is misleading.) }\end{array}$ \\
\hline Satisfaction with job security & $\begin{array}{l}\text { Based on the question: Tell me, please, how satisfied are you with your current } \\
\text { job in terms of job security? (Five answer possibilities as in job satisfaction.) } \\
\text { This question was only asked in the survey years } 2004 \text { and } 2007 \text {. }\end{array}$ \\
\hline \multicolumn{2}{|c|}{ Socio-demographic and household characteristics } \\
\hline $\begin{array}{l}\text { Age_35 (omitted cat.) } \\
\text { Age_3640 } \\
\text { Age_4145 } \\
\text { Age_4650 } \\
\text { Age_51ret }\end{array}$ & $\begin{array}{l}\text { Age group dummy variables according to age calculated using birth year, } \\
\text { month, day and interview year, month, day. Last age group: } 51 \text { to official } \\
\text { retirement age, which is } 55(60) \text { for women(men). }\end{array}$ \\
\hline Male & $=1$, if male; $=0$ otherwise \\
\hline Single (omitted cat.) & $=1$, if marital status is single \\
\hline Married & $=1$, if marital status is married (registered or unregistered marriage) \\
\hline Divorced & $=1$, if marital status is separated or divorced \\
\hline Widowed & $=1$, if marital status is widowed \\
\hline Primary education ${ }^{\mathrm{A})}$ & $=1$, if person has primary or unfinished secondary education \\
\hline General secondary education $^{\mathrm{A})}$ & $=1$, if person has diploma of high-school or PTU with secondary education \\
\hline
\end{tabular}




\begin{tabular}{|c|c|}
\hline & (vocational secondary education) \\
\hline $\begin{array}{l}\text { Professional secondary } \\
\text { education A) }\end{array}$ & $\begin{array}{l}=1 \text {, if person has diploma from college (technical, medical, music, etc.) or } \\
\text { incomplete professional education (at least } 3 \text { years in institute, university, etc.) }\end{array}$ \\
\hline Higher education $^{\mathrm{A})}$ & $\begin{array}{l}=1, \text { if person has diploma from institute/university (bachelor, diploma, } \\
\text { Master, Doctor of science) }\end{array}$ \\
\hline Parents have higher education & $\begin{array}{l}=1 \text {, if at least one parent has diploma from institute/university (bachelor, } \\
\text { diploma, Master, Doctor of science) }\end{array}$ \\
\hline Parents have primary educ. & $=1$, if both parents have primary or unfinished secondary education \\
\hline Chronic disease & $\begin{array}{l}=1 \text {, if person has at least one of seven chronic diseases (self-reported): heart } \\
\text { disease, illness of the lungs, liver disease, kidney disease, gastrointestinal } \\
\text { disease, spinal problems, other chronic illnesses. }\end{array}$ \\
\hline Height & Individual height in $\mathrm{cm}$ \\
\hline One child in $\mathrm{HH}$ & $=1$, if there is one child younger than 18 in the $\mathrm{HH}$ \\
\hline Two or more children in $\mathrm{HH}$ & $=1$, if there are two or more children younger than 18 in the $\mathrm{HH}$ \\
\hline Place of birth: village & Indicating that birth place was village \\
\hline Place of birth: urban settlement & Indicating that birth place was urban settlement \\
\hline Place of birth: town/city & Indicating that birth place was town/city \\
\hline $\begin{array}{l}\text { Place of birth: abroad (omitted } \\
\text { cat.) }\end{array}$ & Indicating that birth place was abroad (not on Ukrainian territory) \\
\hline Never smoked & $=1$, if person has never smoked \\
\hline Extrovert & $\begin{array}{l}\text { Personality trait indicator generated on the basis of interviewer assessment at } \\
\text { the end of the interview. Answer ' } 3 \text { ' to question: Assess the sincerity and } \\
\text { openness of the respondent. The respondent was: } 1 \text {-very introverted, } \\
\text { insincere; } 2 \text { - as sincere and open as most respondents; } 3 \text { - more sincere and } \\
\text { open than most respondents. }\end{array}$ \\
\hline Neurotic & $\begin{array}{l}\text { Personality trait indicator generated on the basis of interviewer assessment at } \\
\text { the end of the interview. Answer ' } 1 \text { ' to question: Assess the respondent's } \\
\text { behaviour during the interview. The respondent: } 1 \text {-was nervous; } 2-\text { was } \\
\text { occasionally nervous; } 3 \text {-felt comfortable. }\end{array}$ \\
\hline Risk loving & $\begin{array}{l}\text { Indicator variable for all persons who answered } 6 \text { or higher on the question: } \\
\text { Are you generally a person who is fully willing to take risks or do you try to } \\
\text { avoid taking risks? Please give me a number from } 0 \text { to } 10 \text {, where the value } 0 \\
\text { means: "Completely unwilling to take risks" and the value } 10 \text { means: } \\
\text { "Completely willing to take risks". Askedonly in the year } 2007 .\end{array}$ \\
\hline \multicolumn{2}{|l|}{ Job characteristics } \\
\hline Professional occupation ${ }^{\mathrm{B})}$ & $\begin{array}{l}=1, \text { if the worker's occupation is in the one-digit ISCO categories of } \\
\text { legislators, senior officials, and managers (1) or professionals }(2) \text {. }\end{array}$ \\
\hline Technician occupation $^{\text {B) }}$ & $\begin{array}{l}=1, \text { if the worker's occupation is in the one-digit ISCO category of } \\
\text { technicians and associate professionals (3). }\end{array}$ \\
\hline $\begin{array}{l}\text { Skilled blue-collar occupation } \\
\text { B) }\end{array}$ & $\begin{array}{l}=1 \text {, if the worker's occupation is in the one-digit ISCO categoriesof clerk (4), } \\
\text { service workers and shop and market sales workers (5), skilled agricultural and } \\
\text { fisheryworkers (6), craft and related workers (7), or plant and machine } \\
\text { operators and assemblers (8). }\end{array}$ \\
\hline $\begin{array}{l}\text { Unskilled occupation (omitted } \\
\text { category) }^{\text {B) }}\end{array}$ & $\begin{array}{l}=1, \text { if the worker's occupation is in the one-digit ISCO category of elementary } \\
\text { occupations ( } 9 \text { ). }\end{array}$ \\
\hline Less than 31 hours & $=1$, if working 30 hours or less in a typical week \\
\hline 31 to 50 hours (omitted cat.) & $=1$, if working between 31 to 50 hours in a typical week \\
\hline More than 50 hours & $=1$, if working 51 hours or more in a typical week \\
\hline Log wage & $\begin{array}{l}\text { Monthly wage (contractual wage) from primary job (after tax), deflated to Dec } \\
2003 \text { Ukrainian Hryvna. Missing wages were imputed based on a standard } \\
\text { Mincer equation controlling for gender, age, schooling, marital status, weekly } \\
\text { working hours, occupational group, settlement type and year dummy variables. }\end{array}$ \\
\hline $\begin{array}{l}\text { Log average monthly industry } \\
\text { wage }\end{array}$ & $\begin{array}{l}\text { Average monthly wages for one digit industry groups; deflated to Dec } 2003 \\
\text { Ukrainian Hryvna (Source: Ukrainian State Statistics Office) }\end{array}$ \\
\hline Weekend work & $=1$, if worked at least once on Saturday and/or Sunday in the past four weeks \\
\hline Shiftwork & $=1$, if worked more than one shift in the past four weeks \\
\hline \multicolumn{2}{|l|}{ Firm characteristics } \\
\hline State sector firm & $\begin{array}{l}\text { Dummy variable with value } 1 \text { if ownership type is any of the following: } \\
\text { Budgetary organization, State enterprise, Local municipal enterprise. The }\end{array}$ \\
\hline
\end{tabular}


variable has been extensively cleaned based on consistency checks across

waves and information on enterprise names. It takes the value 0 for

'Privatized', 'De-novo, private (incl. new agric)', 'Freelance, Self-employed',

'Collectives, Cooperatives', 'Intl' organization; other organization', missings.

$\begin{array}{ll}\text { Small size firm (om. cat.) } & =1, \text { if number of employees }<10 \\ \text { Medium sized firm } & =1, \text { if number of employees } 10-99 \\ \text { Large sized firm } & =1, \text { if number of employees } 100 \text { and more }\end{array}$

Fringe benefits

Social benefits

Three dummy variables based on the survey answers on the following question: In this job do employees receive any of the following social benefits?

SB: Social security $=1$, if answered 'yes' to at least one of following security type benefits (cat: 1 , $2,3,4)^{\mathrm{C})}$

SB: Subsidy

$=1$, if answered 'yes' to at least one of following subsidy type benefits (cat: 6 , $7,8,10,11,12,13)^{\mathrm{C})}$

SB: Training

$=1$, if answered 'yes' to at least one of following quality enhancement type benefits (cat: 9, 5) ${ }^{\mathrm{C})}$

Financial benefits

FB: non-performance related

FB: Performance related end of year at Christmas.)

Based on the survey answers on whether respondent received 'any amount of money in addition to your regular salary' in the past year:

FB: Risk compensation $=1$, if received performance-based bonus or payment scheme involved profitsharing $=1$, if received compensation for non-normal work conditions

Control variables from the Soviet period (December 1986 or 1991)

Place of work 1986: Kiev, $\quad$ Set of 6 dummy variables indicating place of work in December 1986. Where Center, West, East, South, Russia, Other country

Log of wage in Dec. 1986 this information is not available or the respondent started his working life after December 1986, the respective information from December 1991 is used.

Log of wage in Dec. 1991 Expressed in real terms in July 2004 Hryvnia

Wage Dec. 1986 missing Expressed in real terms in July 2004 Hryvnia

Wage Dec. 1991 missing $=1$, if wage information is missing

Worked in Dec. 1986

Worked in Dec. 1991 $=1$, if wage information is missing

Marital status in Dec. 1991: Indicator variable for working status in December 1986

married

Number of own children in

Dec. 1991

Soviet job 1986/91: white collar occupation technicians)

Soviet job 1986/91: has at least $=1$, if has at least one subordinate in Soviet job 1986/91

one subordinate

Soviet job 1986/91: info subordinate - missing

\section{Other controls}

\begin{tabular}{|c|c|}
\hline Oblast & A set of dummy variables for each of the 26 oblasts of Ukraine \\
\hline Urban & $=1$, if settlement has status of small town or more, $=0$, if village \\
\hline Year 2004, Year 2007 & Year fixed effects for survey years (omitted category: year 2003) \\
\hline $\begin{array}{l}\text { Totes: }{ }^{\mathrm{A})} \text { Coded accor } \\
\text { akhitov (2006); }{ }^{\mathrm{C})} \mathrm{S} \\
\text { eave, child care leave } \\
\text { eedical institutions, } 5 \\
\text { are in an enterprise } \mathrm{k} \\
\text { iscounted food/subs } \\
\text { redit. } 11 \text { Possibilities }\end{array}$ & $\begin{array}{l}\text { ts }(2006) ;{ }^{\mathrm{B})} \text { Categories based on one-digit ISCO codes as in Brown, Earle and } \\
\text { answer categories: } 1 \text { Regular paid vacation, } 2 \text { Paid sick leave, } 3 \text { Paid maternity } \\
\text { tment in an enterprise polyclinic, full or partial payment for treatment in other } \\
\mathrm{r} \text { trips to sanatoria, rest homes, tourist bases, or children camps, } 6 \text { Free child } \\
\text { or full or partial payment for child care in another kindergarten, } 7 \text { Free or } \\
\text { sportation subsidies, } 9 \text { Training paid for by the organization, } 10 \text { Loans and } \\
\text { lase garden and land plot at below market prices, } 12 \text { Equipment for additional }\end{array}$ \\
\hline
\end{tabular}


Table A 3: Summary statistics of estimation sample, by sector

\begin{tabular}{|c|c|c|c|c|}
\hline & $\begin{array}{c}\text { Private } \\
\text { sector } \\
\text { Mean }\end{array}$ & $\begin{array}{c}\text { State } \\
\text { sector } \\
\text { Mean }\end{array}$ & \multicolumn{2}{|c|}{$\begin{array}{c}\text { t-statistic } \\
\text { from mean } \\
\text { comparison test }\end{array}$} \\
\hline \multicolumn{5}{|l|}{ Dependent variables } \\
\hline Job Satisfaction (std. dev.: 1.18) & 3.23 & 3.55 & -9.00 & $* * *$ \\
\hline Satisfaction with job security (std. dev.: 1.14) & 3.40 & 3.86 & -10.00 & $* * *$ \\
\hline \multicolumn{5}{|l|}{ Instrumental variables } \\
\hline IV 1 (privatization prob.) (min.: 0.00; max.: 0.48) & 0.17 & 0.11 & 18.97 & $* * *$ \\
\hline IV 2 (private sector share) (min.: 0.00: max.: 0.96) & 0.67 & 0.44 & 23.98 & $* * *$ \\
\hline \multicolumn{5}{|l|}{ Socio-demographic characteristics } \\
\hline Male & 0.53 & 0.39 & 8.68 & $* * *$ \\
\hline Age: 35 or less (omitted category) & 0.12 & 0.10 & 1.80 & $*$ \\
\hline Age: 36 up to 40 & 0.19 & 0.17 & 1.52 & \\
\hline Age: 41 up to 45 & 0.24 & 0.24 & 0.39 & \\
\hline Age: 46 up to 50 & 0.24 & 0.25 & -0.85 & \\
\hline Age: 51 up to retirement age & 0.22 & 0.25 & -2.21 & $* *$ \\
\hline Primary education (omitted category) & 0.09 & 0.05 & 4.82 & $* * *$ \\
\hline General secondary education & 0.46 & 0.39 & 4.71 & $* * *$ \\
\hline Professional secondary education & 0.29 & 0.31 & -1.38 & \\
\hline Higher education & 0.16 & 0.25 & -7.24 & $* * *$ \\
\hline Individual height in $\mathrm{cm}$. & 169.42 & 168.07 & 5.38 & $* * *$ \\
\hline At least one parent has higher education & 0.13 & 0.12 & 0.71 & \\
\hline Both parents have lower education & 0.48 & 0.48 & -0.46 & \\
\hline Single (omitted category) & 0.03 & 0.03 & 0.87 & \\
\hline Married & 0.81 & 0.80 & 0.37 & \\
\hline Divorced & 0.12 & 0.12 & 0.69 & \\
\hline Widowed & 0.03 & 0.05 & -2.57 & $* *$ \\
\hline No children in household (omitted cat.) & 0.49 & 0.50 & -0.91 & \\
\hline One child in household & 0.33 & 0.34 & -0.66 & \\
\hline Two or more children in household & 0.18 & 0.16 & 2.04 & $* *$ \\
\hline Chronic disease & 0.51 & 0.55 & -2.16 & $* *$ \\
\hline Urban settlement & 0.57 & 0.55 & 1.06 & \\
\hline \multicolumn{5}{|l|}{ Job and workplace characteristics } \\
\hline Professional occupation & 0.17 & 0.23 & -4.72 & $* * *$ \\
\hline Technician occupation & 0.09 & 0.21 & -11.06 & $* * *$ \\
\hline Skilled blue collar occupation & 0.52 & 0.37 & 9.77 & $* * *$ \\
\hline Unskilled occupation (omitted cat.) & 0.22 & 0.19 & 2.52 & $* *$ \\
\hline Working hours: 30 or less & 0.08 & 0.13 & -5.11 & $* * *$ \\
\hline Working hours: 31 up to 50 (omit. cat.) & 0.74 & 0.84 & -7.56 & $* * *$ \\
\hline Working hours: 51 or more & 0.17 & 0.03 & 15.80 & $* * *$ \\
\hline Firm size 1-9 (omitted category) & 0.29 & 0.09 & 17.72 & $* * *$ \\
\hline Firm size 10-99 & 0.30 & 0.41 & -7.91 & $* * *$ \\
\hline Firm size 100 and more & 0.41 & 0.50 & -5.78 & $* * *$ \\
\hline Log earnings & 5.83 & 5.79 & 2.07 & $* *$ \\
\hline Log average industry wage & 6.30 & 6.27 & 2.83 & $* * *$ \\
\hline
\end{tabular}


Table A 3 continued

Weekend work

$\begin{array}{llll}0.54 & 0.37 & 10.75 & * * * \\ 0.13 & 0.15 & -1.96 & * *\end{array}$

$\begin{array}{llrl}0.13 & 0.17 & -3.90 & * * * \\ 0.02 & 0.02 & 1.46 & \\ 0.46 & 0.58 & -7.35 & * * * \\ 0.24 & 0.19 & 3.89 & * * *\end{array}$

Risk loving

0.24

0.44

0.46

$-1.64$

Place of birth: village

0.07

0.11

$-4.47 * * *$

Place of birth: town/city

0.39

0.34

$3.50 * * *$

Place of birth: abroad (omitted cat.)

0.11

0.10

1.29

Place of work 1986: Kiev

0.05

0.06

$-1.17$

Place of work 1986: Centre

0.25

0.24

0.50

Place of work 1986: West

0.14

0.20

$-5.26 * * *$

Place of work 1986: East

0.23

0.25

$-1.36$

Place of work 1986: South

0.27

0.21

$5.01 * * *$

Place of work 1986: Russia (omitted cat.)

0.03

0.02

$1.84 *$

Place of work 1986: other (omitted cat.)

0.02

0.01

1.49

Marital status in Dec. 1991: married

0.85

0.89

$-3.55 * * *$

Number of own children in Dec. 1991

1.43

1.50

$-2.27 * *$

Log of wage in December 1986

$-5.62$

$-5.86$

1.88

Log of wage in December 1991

$-5.45$

$-5.56$

0.84

Wage December 1986 missing

0.36

0.34

1.49

Wage December 1991 missing

0.37

0.36

0.58

Worked in Dec 1986

0.78

0.82

$-3.34 * * *$

Worked in Dec 1991

0.96

0.96

0.55

Soviet job 1986/91: white collar occupation ${ }^{\text {A) }}$

0.30

0.46

$-10.53 * * *$

Soviet job 1986/91: has at least one subordinate

0.14

0.18

$-2.77$

Soviet job 1986/91: info subordinate - missing

0.20

0.13

$6.25 * * *$

Number of observations

2,035

2,156

Notes: Pooled sample of all individuals in working age during time of interview with full information on all variables, who were 16 or older in December 1991 and for whom information on their job during the Soviet time (December 1986 or December 1991) exist. Reported t-statistics refer to mean comparison tests between state and private sector; $* * * \mathrm{p}<0.01, * * \mathrm{p}<0.05, * \mathrm{p}<0.1$. The regressions include furthermore: 2 survey year dummy variables, 25 oblast dummy variables, 8 interview month dummy variables. ${ }^{\text {A) }}$ Professionals and technicians. Source: ULMS 2003-2007; own calculations. 
Table A 4: Job satisfaction regressions with stepwise inclusion of covariates (a more complete representation of Table 1) (GLS)

\begin{tabular}{|c|c|c|c|c|c|c|}
\hline \multirow[b]{2}{*}{ Dependent variable } & (1) & (2) & (3) & (4) & (5) & (6) \\
\hline & \multicolumn{6}{|c|}{ Job satisfaction } \\
\hline State sector & $\begin{array}{c}0.340 * * * \\
(0.043)\end{array}$ & $\begin{array}{c}0.277 * * * \\
(0.042)\end{array}$ & $\begin{array}{c}0.266 * * * \\
(0.043)\end{array}$ & $\begin{array}{c}0.219 * * * \\
(0.043)\end{array}$ & $\begin{array}{c}0.220 * * * \\
(0.041)\end{array}$ & $\begin{array}{c}0.212 * * * \\
(0.041)\end{array}$ \\
\hline Male & & $\begin{array}{l}-0.064 \\
(0.062)\end{array}$ & $\begin{array}{l}-0.035 \\
(0.066)\end{array}$ & $\begin{array}{l}-0.072 \\
(0.065)\end{array}$ & $\begin{array}{c}-0.172 * * * \\
(0.063)\end{array}$ & $\begin{array}{l}-0.133 * \\
(0.076)\end{array}$ \\
\hline Age: 36 - 40 & & $\begin{array}{c}0.027 \\
(0.069)\end{array}$ & $\begin{array}{c}0.065 \\
(0.076)\end{array}$ & $\begin{array}{c}0.073 \\
(0.075)\end{array}$ & $\begin{array}{c}0.052 \\
(0.073)\end{array}$ & $\begin{array}{c}0.055 \\
(0.073)\end{array}$ \\
\hline Age: 41 - 45 & & $\begin{array}{l}-0.029 \\
(0.072)\end{array}$ & $\begin{array}{c}0.028 \\
(0.090)\end{array}$ & $\begin{array}{c}0.054 \\
(0.089)\end{array}$ & $\begin{array}{c}0.046 \\
(0.086)\end{array}$ & $\begin{array}{c}0.040 \\
(0.086)\end{array}$ \\
\hline Age: 46 - 50 & & $\begin{array}{l}-0.015 \\
(0.077)\end{array}$ & $\begin{array}{c}0.054 \\
(0.100)\end{array}$ & $\begin{array}{c}0.087 \\
(0.098)\end{array}$ & $\begin{array}{c}0.091 \\
(0.095)\end{array}$ & $\begin{array}{c}0.084 \\
(0.095)\end{array}$ \\
\hline Age: 51 - retirement age & & $\begin{array}{c}0.063 \\
(0.082)\end{array}$ & $\begin{array}{c}0.134 \\
(0.106)\end{array}$ & $\begin{array}{c}0.159 \\
(0.104)\end{array}$ & $\begin{array}{l}0.185^{*} \\
(0.101)\end{array}$ & $\begin{array}{l}0.179^{*} \\
(0.102)\end{array}$ \\
\hline General secondary educ. & & $\begin{array}{c}0.026 \\
(0.076)\end{array}$ & $\begin{array}{c}0.028 \\
(0.076)\end{array}$ & $\begin{array}{c}0.019 \\
(0.078)\end{array}$ & $\begin{array}{l}-0.002 \\
(0.075)\end{array}$ & $\begin{array}{l}-0.001 \\
(0.075)\end{array}$ \\
\hline Professional sec. educ. & & $\begin{array}{c}0.197 * * \\
(0.081)\end{array}$ & $\begin{array}{c}0.130 \\
(0.083)\end{array}$ & $\begin{array}{c}0.040 \\
(0.086)\end{array}$ & $\begin{array}{c}0.003 \\
(0.084)\end{array}$ & $\begin{array}{c}0.004 \\
(0.084)\end{array}$ \\
\hline Higher education & & $\begin{array}{c}0.413 * * * \\
(0.088)\end{array}$ & $\begin{array}{c}0.282 * * * \\
(0.094)\end{array}$ & $\begin{array}{c}0.054 \\
(0.103)\end{array}$ & $\begin{array}{c}0.020 \\
(0.101)\end{array}$ & $\begin{array}{c}0.014 \\
(0.101)\end{array}$ \\
\hline Individual height & & $\begin{array}{c}0.001 \\
(0.004)\end{array}$ & $\begin{array}{c}0.001 \\
(0.004)\end{array}$ & $\begin{array}{c}0.000 \\
(0.003)\end{array}$ & $\begin{array}{l}-0.000 \\
(0.003)\end{array}$ & $\begin{array}{l}-0.000 \\
(0.003)\end{array}$ \\
\hline Parents: higher educ. & & $\begin{array}{c}0.110 \\
(0.068)\end{array}$ & $\begin{array}{c}0.107 \\
(0.068)\end{array}$ & $\begin{array}{c}0.095 \\
(0.067)\end{array}$ & $\begin{array}{c}0.103 \\
(0.065)\end{array}$ & $\begin{array}{l}0.106^{*} \\
(0.064)\end{array}$ \\
\hline Parents: primary educ. & & $\begin{array}{c}-0.009 \\
(0.049)\end{array}$ & $\begin{array}{l}-0.004 \\
(0.049)\end{array}$ & $\begin{array}{c}-0.003 \\
(0.047)\end{array}$ & $\begin{array}{c}0.001 \\
(0.045)\end{array}$ & $\begin{array}{c}0.004 \\
(0.045)\end{array}$ \\
\hline Married & & $\begin{array}{c}0.367 * * * \\
(0.114)\end{array}$ & $\begin{array}{c}0.454 * * * \\
(0.123)\end{array}$ & $\begin{array}{c}0.430 * * * \\
(0.123)\end{array}$ & $\begin{array}{c}0.419 * * * \\
(0.117)\end{array}$ & $\begin{array}{c}0.428 * * * \\
(0.118)\end{array}$ \\
\hline Divorced & & $\begin{array}{c}0.305^{* *} \\
(0.121)\end{array}$ & $\begin{array}{c}0.378 * * * \\
(0.129)\end{array}$ & $\begin{array}{c}0.356^{* * * *} \\
(0.129)\end{array}$ & $\begin{array}{c}0.368 * * * \\
(0.122)\end{array}$ & $\begin{array}{c}0.383^{* * * *} \\
(0.124)\end{array}$ \\
\hline Widowed & & $\begin{array}{c}0.413 * * * \\
(0.147)\end{array}$ & $\begin{array}{c}0.516^{* * * *} \\
(0.155)\end{array}$ & $\begin{array}{c}0.499 * * * \\
(0.154)\end{array}$ & $\begin{array}{c}0.483 * * * \\
(0.149)\end{array}$ & $\begin{array}{c}0.493 * * * \\
(0.150)\end{array}$ \\
\hline 1 child in $\mathrm{HH}$ & & $\begin{array}{c}-0.084 * \\
(0.045)\end{array}$ & $\begin{array}{c}-0.076^{*} \\
(0.046)\end{array}$ & $\begin{array}{l}-0.080^{*} \\
(0.044)\end{array}$ & $\begin{array}{l}-0.069 \\
(0.043)\end{array}$ & $\begin{array}{l}-0.071 \\
(0.043)\end{array}$ \\
\hline $2+$ children in $\mathrm{HH}$ & & $\begin{array}{c}-0.155^{* * *} * \\
(0.057)\end{array}$ & $\begin{array}{c}-0.131 * * \\
(0.058)\end{array}$ & $\begin{array}{l}-0.112 * \\
(0.058)\end{array}$ & $\begin{array}{l}-0.091 \\
(0.057)\end{array}$ & $\begin{array}{l}-0.095^{*} \\
(0.057)\end{array}$ \\
\hline Chronic disease & & $\begin{array}{c}-0.203 * * * \\
(0.037)\end{array}$ & $\begin{array}{c}-0.197 * * * \\
(0.037)\end{array}$ & $\begin{array}{c}-0.183 * * * \\
(0.037)\end{array}$ & $\begin{array}{c}-0.172 * * * \\
(0.036)\end{array}$ & $\begin{array}{c}-0.171 * * * \\
(0.036)\end{array}$ \\
\hline Urban settlement & & $\begin{array}{c}0.135 * * * \\
(0.052)\end{array}$ & $\begin{array}{c}0.117 * * \\
(0.052)\end{array}$ & $\begin{array}{c}0.066 \\
(0.052)\end{array}$ & $\begin{array}{l}-0.003 \\
(0.051)\end{array}$ & $\begin{array}{l}-0.005 \\
(0.051)\end{array}$ \\
\hline Professional occupation & & & & $\begin{array}{c}0.619 * * * \\
(0.076)\end{array}$ & $\begin{array}{c}0.429 * * * \\
(0.078)\end{array}$ & $\begin{array}{c}0.417 * * * \\
(0.078)\end{array}$ \\
\hline Technical occupation & & & & $\begin{array}{c}0.465 * * * \\
(0.075)\end{array}$ & $\begin{array}{c}0.372 * * * \\
(0.073)\end{array}$ & $\begin{array}{c}0.364 * * * \\
(0.073)\end{array}$ \\
\hline Skilled blue collar occ. & & & & $\begin{array}{c}0.255^{* * *} * \\
(0.054)\end{array}$ & $\begin{array}{c}0.145^{* * *} * \\
(0.053)\end{array}$ & $\begin{array}{c}0.142 * * * \\
(0.053)\end{array}$ \\
\hline Less than 31 hours & & & & $\begin{array}{c}-0.351^{* * * *} \\
(0.065)\end{array}$ & $\begin{array}{c}-0.190 * * * \\
(0.065)\end{array}$ & $\begin{array}{c}-0.198 * * * \\
(0.065)\end{array}$ \\
\hline More than 50 hours & & & & $\begin{array}{c}-0.091 \\
(0.062)\end{array}$ & $\begin{array}{c}-0.103^{*} \\
(0.062)\end{array}$ & $\begin{array}{c}-0.081 \\
(0.063)\end{array}$ \\
\hline
\end{tabular}


Table A4 continued

Medium-sized firm

$0.094 \quad 0.096^{*} \quad 0.080$

$\begin{array}{lll}(0.058) & (0.056) & (0.056)\end{array}$

Large-sized firm

$0.139 * *$

0.064

0.049

Log earnings

(0.058)

$(0.056)$

$(0.057)$

$0.392 * * * \quad 0.394 * * *$

(0.047)

(0.048)

Log average industry wage

$0.192 * * * \quad 0.176 * *$

(0.073)

$(0.074)$

Weekend work

Shift work

Extrovert

Neurotic

Never smoked

Risk loving

Constant

Chi-square test

194.7

475.1

504.8



850.1

870.9

Prob > chi2

0

0
$\checkmark$
$\checkmark$
-

0

Region FE

Age \& birth place

Soviet period controls

R-squared overall

0.0430

0.106

0.112

0.144

\section{0}

Notes: Dependent variable: five-point Likert scale of job satisfaction with $1=$ fully dissatisfied to $5=$ fully satisfied. All regressions control for interview year and month fixed effects. Omitted categories: "aged 35 or younger," "primary education," "single," "occupation: unskilled," "working hours: 31 to 50 hours," "small-sized firm," "village/rural settlement." The set of "Soviet period controls" contains controls for place of work in 1986, $\log$ of wage in 1986 and 1991, a dummy for Soviet white collar occupation (1986/91 job) and having subordinates in Soviet job (1986/91). Number of observations 4,191 (number of id: 1,915). Standard errors are clustered on the individual level. Robust standard errors are shown in parentheses. *** $\mathrm{p}<0.01, * * \mathrm{p}<0.05$, * p $<0.1$; Source: ULMS 2003-2007; own calculations. 
Table A 5: Robustness checks I.: A. OLS estimates of job satisfaction based on crosssection 2003 only; B. GLS Random effects estimates based on larger sample (ULMS 2003-2007)

\begin{tabular}{|c|c|c|c|c|c|c|}
\hline & \multicolumn{3}{|c|}{$\begin{array}{c}\text { A. } \\
\text { OLS estimates based on } \\
\text { cross-section ULMS } 2003\end{array}$} & \multicolumn{3}{|c|}{$\begin{array}{c}\text { B. } \\
\begin{array}{c}\text { GLS Random effects estimates } \\
\text { based on }\end{array} \\
\text { larger sample (ULMS 2003- } \\
\text { 2007) } \\
\end{array}$} \\
\hline & (1) & (2) & (3) & (4) & (5) & (6) \\
\hline State sector & $\begin{array}{l}0.308 * * * \\
(0.064)\end{array}$ & $\begin{array}{l}0.221 * * * \\
(0.066)\end{array}$ & $\begin{array}{l}0.192 * * * \\
(0.066)\end{array}$ & $\begin{array}{c}0.321 * * * \\
(0.038)\end{array}$ & $\begin{array}{c}0.255^{* * *} \\
(0.039)\end{array}$ & $\begin{array}{c}0.208 * * * \\
(0.038)\end{array}$ \\
\hline $\begin{array}{l}\text { Socio-demographic Post-Soviet } \\
\& \text { Soviet characteristics }\end{array}$ & - & $\checkmark$ & $\checkmark$ & - & $\checkmark$ & $\checkmark$ \\
\hline $\begin{array}{l}\text { Current job \& firm } \\
\text { characteristics (incl. earnings) }\end{array}$ & - & - & $\checkmark$ & - & - & $\checkmark$ \\
\hline Personality traits, risk aversion & - & - & $\checkmark$ & - & - & $\checkmark$ \\
\hline Observations & 1,491 & 1,491 & 1,491 & 5,142 & 5,142 & 5,142 \\
\hline R-squared ${ }^{\text {A) }}$ & 0.0157 & 0.0986 & 0.185 & 0.0381 & 0.103 & 0.182 \\
\hline
\end{tabular}

Notes: Dependent variable: Five-point Likert scale of job satisfaction with 1 (fully dissatisfied) to 5 (fully satisfied). Omitted categories: 'primary education', 'single', 'occupation: unskilled', 'works 31 to 50 hours in typical working week', 'small-sized firm', 'village or rural settlement'. The table reports only the estimated coefficients of interest (state sector; instrumental variables) from the following regression specifications: columns (1) and (4) correspond to the specifications in Table 1, column (1); columns (2) and (5) correspond to Table 1, column (3); columns (3) and (6) correspond to Table 1, column (4). ${ }^{\text {A) }}$ Standard R-squared in columns (1)-(3); R-squared overall in columns (4)-(6). Number of id in columns (4)-(6): 2,566. All regressions control for year and interview month fixed effects. Standard errors are clustered on the individual level. Robust standard errors are shown in parentheses; *** $\mathrm{p}<0.01, * * \mathrm{p}<0.05, * \mathrm{p}<0.1$. Source: columns (1)-(3) ULMS 2003, columns (4)-(6) ULMS 2003-2007; own calculations. 
Table A 6: Robustness checks II: Instrumental variable regressions based on (A) crosssection 2003 and (B) pooled sample with more observations (ULMS 20032007)

Instrumental variable 1:

Privatization probability

(1) (2) (3)

Job Satisfaction
Instrumental variable 2:

Private sector share

(4) (5) (6)

Job Satisfaction

Dependent variable

A. OLS estimates based on cross-section ULMS 2003

OLS regressions

\begin{tabular}{lcccccc} 
State sector & $0.308 * * *$ & $0.221 * * *$ & $0.192 * * *$ & $0.308 * * *$ & $0.221 * * *$ & $0.192 * * *$ \\
& $(0.064)$ & $(0.066)$ & $(0.066)$ & $(0.064)$ & $(0.066)$ & $(0.066)$ \\
& & & & & & \\
2SLS regressions & & & & & & \\
State sector & $0.635 * * *$ & 0.326 & $0.519 * *$ & $0.858^{* * *}$ & $0.531 * * *$ & $0.571 * * *$ \\
& $(0.224)$ & $(0.230)$ & $(0.253)$ & $(0.183)$ & $(0.178)$ & $(0.184)$ \\
& & & & & & \\
First stage t-statistic & -8.87 & -9.39 & -9.82 & -12.55 & -11.60 & -9.47 \\
First stage F-statistic & 78.60 & 88.18 & 96.40 & 157.44 & 134.51 & 89.77 \\
Observations & 1,491 & 1,491 & 1,491 & 1,491 & 1,491 & 1,491 \\
\hline
\end{tabular}

B. GLS Random effects estimates based on larger sample (ULMS 2003-2007)

GLS regressions

$\begin{array}{lcccccc}\text { State sector } & 0.321^{* * *} & 0.255^{* * *} & 0.208^{* * *} & 0.321 * * * & 0.255^{* * *} & 0.208^{* * *} \\ & (0.038) & (0.039) & (0.038) & (0.038) & (0.039) & (0.038) \\ \text { G2SLS regressions } & & & & & & \\ \text { State sector } & & & & & & \\ & 0.553^{* * *} & 0.303 * & 0.412 * * & 0.812^{* * *} & 0.466^{* * * *} & 0.441^{* * *} \\ & (0.148) & (0.173) & (0.172) & (0.115) & (0.130) & (0.142) \\ \text { First stage z-statistic } & & & & & & \\ \text { First stage chi-2-statistic } & -18.48 & -15.66 & -15.81 & -24.81 & -21.37 & -19.44 \\ \text { Observations } & 193.1 & 130.3 & 140.7 & 396.5 & 267.9 & 237.5 \\ & 5,142 & 5,142 & 5,142 & 5,142 & 5,142 & 5,142\end{array}$

Socio-demographic Post-Soviet

and Soviet characteristics

Current job and firm

characteristic (incl. earnings)

Personality traits, risk aversion

Notes: Dependent variable: Five-point Likert scale of job satisfaction with 1 (fully dissatisfied) to 5 (fully satisfied). The table reports only the estimated coefficients of interest (state sector; instrumental variables) from the following regression specifications: columns (1) and (4) correspond to the specifications in Table 1, column (1); columns (2) and (5) correspond to Table 1, column (3); columns (3) and (6) correspond to Table 1, column (4). In panel (A) the estimation procedure allows to cluster standard errors on industry-macro region level; in panel (B) standard errors are clustered on the individual level. In the top panel A, the p-value for the state sector coefficient from the 2SLS regression in column (2) is 0.157. Robust standard errors are shown in parentheses; *** $\mathrm{p}<0.01, * * \mathrm{p}<0.05, * \mathrm{p}<0.1$; Source: ULMS 2003-2007; own calculations. 


\section{Appendix B. Construction of instrumental variables}

\section{First Instrumental Variable: Share of Employees experiencing privatization in 27 industries}

The first instrumental variable reflects the probability of experiencing subsequent privatization of one's Soviet workplace in a specific industry sector. The calculation of the instrumental variable exploits the retrospective work histories of the ULMS 2003. It is based on the sample of individuals starting their jobs during the Soviet period and who stayed in these jobs at least until January 1993, i.e. until the start of the mass privatization process (creating a sample of 4,451 individual 'transition jobs'). The calculation of industry specific privatization probabilities involves two steps: (1) First, a binary indicator is generated for each 'transition job' taking the value ' 1 ' if the workplace was privatized during the tenure of the job and if most of the shares of the enterprise/organization were owned by private entities after the privatization, and ' 0 ' otherwise. (2) Second, these binary privatization indicators are used to calculate the share of privatized jobs within 27 different industry sectors (see Table B 1 for the calculated privatization probabilities and the respective cell sizes). These industry specific privatization probabilities are assigned to workers according to the industry in which they used to work in December 1986. For the subsample of workers who did not work in December 1986, but started to work before December 1991, the industry specific privatization probability is assigned according to the industry of their job held in December 1991. Note, that there are two aspects that potentially reduce the exactness of this instrumental variable in reflecting the true industry specific privatization probability. First, the ULMS survey was originally designed to be representative of the Ukrainian population aged 15 to 72 in 2003 and not in 1986/1991. This implies that the true privatization probabilities might differ to the extent that the distribution of workers across industries based on the retrospective information of the sample 2003 differs from the actual distribution (if, for instance, mortality rates or migration vary across industries). Second, the construction of the instrumental variable is based only on those jobs that started during the Soviet period and thus neglects all possible privatization experiences after a job change in the Post-Soviet period. However, this will only bias the estimates if the workers propensity to leave a 'still state-owned' enterprise before its privatization differs systematically across sectors. 
Table B 1: Overview of the share of privatized jobs across industries (ULMS)

\begin{tabular}{|c|c|c|c|}
\hline \multicolumn{2}{|c|}{ Industry sector categories I (ULMS) } & \multirow{2}{*}{$\begin{array}{c}\text { Privatization } \\
\text { probability (IV 1) } \\
14.76 \%\end{array}$} & \multirow{2}{*}{$\begin{array}{c}\begin{array}{c}\text { Number of } \\
\text { observations } \\
\text { per cell }\end{array} \\
725\end{array}$} \\
\hline 1 & Agriculture, forestry, fishing & & \\
\hline 2 & Mining & $6.27 \%$ & 257 \\
\hline 3 & Manufacture of foodstuffs, beverages and tobacco & $24.60 \%$ & 189 \\
\hline 4 & Manufacture of textiles and leather products & $34.62 \%$ & 132 \\
\hline 5 & $\begin{array}{l}\text { Manufacture of cellulose and paper industry; wood; } \\
\text { printing }\end{array}$ & $35.94 \%$ & 64 \\
\hline 6 & $\begin{array}{l}\text { Manufacture of coke, refined petroleum products and } \\
\text { nuclear fuel }\end{array}$ & $28.57 \%$ & 14 \\
\hline 7 & Manufacture of chemicals and chemical products & $23.91 \%$ & 46 \\
\hline 8 & Manufacture of rubber and plastic products & $48.39 \%$ & 31 \\
\hline 9 & Manufacture of other non-metallic mineral products & $29.17 \%$ & 24 \\
\hline 10 & Metallurgy and production of finished metal products & $32.27 \%$ & 223 \\
\hline 11 & Manufacture of machinery and equipment & $24.79 \%$ & 123 \\
\hline 12 & Manufacture of electrical, electronic and optical equipment & $21.28 \%$ & 189 \\
\hline 13 & Manufacture of transport vehicles and equipment & $29.66 \%$ & 119 \\
\hline 14 & Manufacture other & $26.32 \%$ & 19 \\
\hline 15 & Production and distribution of electricity, gas and water & $16.46 \%$ & 79 \\
\hline 16 & Construction & $12.66 \%$ & 242 \\
\hline 17 & $\begin{array}{l}\text { Trade; repair of motor vehicles, household appliances, } \\
\text { personal demand items }\end{array}$ & $15.77 \%$ & 283 \\
\hline 18 & Activity of hotels and restaurants & $13.51 \%$ & 37 \\
\hline 19 & Transport & $11.32 \%$ & 318 \\
\hline 20 & Post and Telecom & $6.67 \%$ & 60 \\
\hline 21 & Financial intermediaries & $8.82 \%$ & 68 \\
\hline 22 & Public administration and defence & $1.01 \%$ & 198 \\
\hline 23 & Education & $0.24 \%$ & 419 \\
\hline 24 & Health care and provision of social aid & $1.48 \%$ & 341 \\
\hline 25 & Provision of communal and individual services & $8.19 \%$ & 172 \\
\hline 26 & $\begin{array}{l}\text { Communal and individual services: culture, sport, leisure, } \\
\text { entertainment }\end{array}$ & $5.26 \%$ & 57 \\
\hline \multirow[t]{2}{*}{27} & Other activities & $0.00 \%$ & 22 \\
\hline & Total & $13.99 \%$ & 4,451 \\
\hline
\end{tabular}

\section{Second Instrumental Variable: Share of Private Sector Employment in 16 industries in 5 macro regions in Post-Soviet Ukraine (2003-2006)}

The construction of the second instrumental variable is based on a pooled sample of four cross-sections of the Ukrainian Budget Household Survey (UHBS) for the years 2003 to 2006. The calculation is based on individuals who work at the time of the interview (excluding unpaid family helpers) and have non-missing information on industry category and ownership type of workplace $(\mathrm{N}=34,344)$. There are 7 different answer possibilities for workplace ownership: (1) Public/State enterprise, organization, office/institute; (2) Collective 
enterprise, cooperative; (3) Joint stock enterprise; (4) Leased enterprise; (5) Joint venture or foreign enterprise; (6) Private enterprise or private individual/person; (7) Other. The UHBS questionnaire distinguishes 17 industry sectors (16 categories are used for constructing cell shares as two categories were merged due to few observations per cell). The instrumental variable reflects the share of individuals working in the private sector (i.e., not working for a public/state enterprise, organization) among all workers in a specific industry sector and macro-region of Ukraine. Overall, there are 80 industry-region cells with different private sector shares (16 industries x 5 macro regions). All cell shares are calculated using individual sampling weights provided in the UHBS.

Table B 2: Overview of industry-region categories and industry-region specific shares of private sector employment in the UHBS

\begin{tabular}{|c|c|c|c|}
\hline Region & Industry sector categories II (UHBS) & $\begin{array}{l}\text { Private sector } \\
\text { share (IV 2) }\end{array}$ & $\begin{array}{c}\text { Number of } \\
\text { observations } \\
\text { per cell }\end{array}$ \\
\hline Kiev & Agriculture, hunting and forestry & $30.94 \%$ & 15 \\
\hline Kiev & Fishery & $75.65 \%$ & 5 \\
\hline Kiev & Mining & $44.48 \%$ & 17 \\
\hline Kiev & Manufacturing & $55.85 \%$ & 225 \\
\hline Kiev & Production and distribution of electricity, gas and water & $34.39 \%$ & 33 \\
\hline Kiev & Construction & $72.66 \%$ & 207 \\
\hline Kiev & $\begin{array}{l}\text { Wholesale and retail trade; sale of transportation means; } \\
\text { repair services }\end{array}$ & $88.61 \%$ & 339 \\
\hline Kiev & Hotels and restaurants & $89.82 \%$ & 44 \\
\hline Kiev & Transport and communications & $52.64 \%$ & 222 \\
\hline Kiev & Financial intermediation & $61.71 \%$ & 87 \\
\hline Kiev & Real estate transactions, lease and services to legal persons & $35.55 \%$ & 86 \\
\hline Kiev & Public administration & $1.27 \%$ & 166 \\
\hline Kiev & Education & $6.62 \%$ & 218 \\
\hline Kiev & Health care and social aid & $14.50 \%$ & 144 \\
\hline Kiev & Collective, social and individual services & $64.50 \%$ & 264 \\
\hline Kiev & Extra-territorial organizations and bodies & $51.30 \%$ & 12 \\
\hline Centre & Agriculture, hunting and forestry & $83.25 \%$ & 1587 \\
\hline Centre & Fishery & $84.55 \%$ & 15 \\
\hline Centre & Mining & $70.72 \%$ & 132 \\
\hline Centre & Manufacturing & $87.32 \%$ & 1249 \\
\hline Centre & Production and distribution of electricity, gas and water & $44.90 \%$ & 276 \\
\hline Centre & Construction & $80.92 \%$ & 466 \\
\hline Centre & $\begin{array}{l}\text { Wholesale and retail trade; sale of transportation means; } \\
\text { repair services }\end{array}$ & $95.21 \%$ & 917 \\
\hline Centre & Hotels and restaurants & $85.53 \%$ & 90 \\
\hline Centre & Transport and communications & $42.68 \%$ & 674 \\
\hline Centre & Financial intermediation & $55.06 \%$ & 130 \\
\hline Centre & Real estate transactions, lease and services to legal persons & $58.49 \%$ & 62 \\
\hline Centre & Public administration & $0.53 \%$ & 624 \\
\hline Centre & Education & $0.41 \%$ & 1010 \\
\hline Centre & Health care and social aid & $5.34 \%$ & 793 \\
\hline Centre & Collective, social and individual services & $59.55 \%$ & 271 \\
\hline Centre & Extra-territorial organizations and bodies & $51.30 \%$ & 12 \\
\hline
\end{tabular}




\begin{tabular}{|c|c|c|c|}
\hline West & Agriculture, hunting and forestry & $77.86 \%$ & 839 \\
\hline West & Fishery & $91.72 \%$ & 5 \\
\hline West & Mining & $47.45 \%$ & 202 \\
\hline West & Manufacturing & $82.37 \%$ & 1122 \\
\hline West & Production and distribution of electricity, gas and water & $43.37 \%$ & 334 \\
\hline West & Construction & $81.20 \%$ & 714 \\
\hline West & $\begin{array}{l}\text { Wholesale and retail trade; sale of transportation means; } \\
\text { repair services }\end{array}$ & $93.88 \%$ & 1046 \\
\hline West & Hotels and restaurants & $90.14 \%$ & 160 \\
\hline West & Transport and communications & $38.69 \%$ & 681 \\
\hline West & Financial intermediation & $42.68 \%$ & 117 \\
\hline West & Real estate transactions, lease and services to legal persons & $55.36 \%$ & 49 \\
\hline West & Public administration & $0.66 \%$ & 793 \\
\hline West & Education & $0.60 \%$ & 1215 \\
\hline West & Health care and social aid & $7.10 \%$ & 863 \\
\hline West & Collective, social and individual services & $55.36 \%$ & 339 \\
\hline West & Extra-territorial organizations and bodies & $51.30 \%$ & 12 \\
\hline East & Agriculture, hunting and forestry & $92.14 \%$ & 423 \\
\hline East & Fishery & $92.48 \%$ & 9 \\
\hline East & Mining & $20.93 \%$ & 565 \\
\hline East & Manufacturing & $84.37 \%$ & 1368 \\
\hline East & Production and distribution of electricity, gas and water & $33.82 \%$ & 301 \\
\hline East & Construction & $86.23 \%$ & 358 \\
\hline East & $\begin{array}{l}\text { Wholesale and retail trade; sale of transportation means; } \\
\text { repair services }\end{array}$ & $95.74 \%$ & 891 \\
\hline East & Hotels and restaurants & $91.76 \%$ & 64 \\
\hline East & Transport and communications & $46.50 \%$ & 505 \\
\hline East & Financial intermediation & $49.50 \%$ & 93 \\
\hline East & Real estate transactions, lease and services to legal persons & $42.81 \%$ & 97 \\
\hline East & Public administration & $0.52 \%$ & 399 \\
\hline East & Education & $1.80 \%$ & 640 \\
\hline East & Health care and social aid & $10.14 \%$ & 515 \\
\hline East & Collective, social and individual services & $58.07 \%$ & 170 \\
\hline East & Extra-territorial organizations and bodies & $51.30 \%$ & 12 \\
\hline South & Agriculture, hunting and forestry & $82.46 \%$ & 1146 \\
\hline South & Fishery & $88.99 \%$ & 41 \\
\hline South & Mining & $73.95 \%$ & 212 \\
\hline South & Manufacturing & $79.56 \%$ & 1492 \\
\hline South & Production and distribution of electricity, gas and water & $33.47 \%$ & 290 \\
\hline South & Construction & $87.98 \%$ & 622 \\
\hline South & $\begin{array}{l}\text { Wholesale and retail trade; sale of transportation means; } \\
\text { repair services }\end{array}$ & $96.11 \%$ & 1254 \\
\hline South & Hotels and restaurants & $91.88 \%$ & 144 \\
\hline South & Transport and communications & $46.84 \%$ & 800 \\
\hline South & Financial intermediation & $55.19 \%$ & 155 \\
\hline South & Real estate transactions, lease and services to legal persons & $62.32 \%$ & 76 \\
\hline South & Public administration & $0.17 \%$ & 579 \\
\hline South & Education & $2.25 \%$ & 865 \\
\hline South & Health care and social aid & $8.38 \%$ & 734 \\
\hline South & Collective, social and individual services & $65.69 \%$ & 332 \\
\hline South & Extra-territorial organizations and bodies & $51.30 \%$ & 12 \\
\hline Total & & $52.77 \%$ & 33,994 \\
\hline
\end{tabular}

